\title{
Estimating Aggregate Capital Stocks Using the Perpetual Inventory Method
}

\author{
- A Survey of Previous Implementations \\ and New Empirical Evidence for 103 Countries - \\ Michael BerlemanN ${ }^{*}$ and JAN-ERIK Wesselhöft ${ }^{* *}$
}

\begin{abstract}
Almost all attempts to construct capital stock data base on some variant of the Perpetual Inventory Method. While various countries employ this method to construct suitable proxies of national capital stocks, the implementation and the underlying assumptions differ considerably, thereby rendering the results internationally incomparable. Only a few attempts to construct internationally comparable capital stock data have yet been undertaken in the scientific literature. In this paper we outline the idea of the Perpetual Inventory Method and deliver a survey of previous implementations of the method. Based on a critical assessment of these implementations we propose a unified approach and construct estimations of aggregate capital stocks for the 1970 to 2010 period for 103 countries.
\end{abstract}

Keywords: aggregate capital stock, investments, Perpetual Inventory Method

\section{JEL codes: O47}

\section{Introduction}

In theoretical models of economic growth the physical capital stock (consisting of machinery, buildings, computers etc.) is one of the major input factors of the production function. In order to study the contribution of the existing capital stock to aggregate output, data on the capital stock is urgently necessary. Since the capital stock of a country is not directly observable, appropriate estimation techniques have to be applied to construct measures of the capital stock. However, in order to be able to

* Helmut-Schmidt-University Hamburg, Faculty of Economics \& Social Sciences, Holstenhofweg 85, 22008 Hamburg, Germany, e-mail: Michael.Berlemann@hsu-hh.de, CESifo Munich and ifo Institute of Economic Research Munich.

** Helmut-Schmidt-University Hamburg, Faculty of Economics \& Social Sciences, Holstenhofweg 85, 22008 Hamburg, Germany. 
apply these techniques, reliable data is urgently necessary. As a consequence, for most countries no suitable capital stock data have been available for long periods of time.

Nowadays, at least many industrial countries spend substantial effort on estimating their capital stocks. ${ }^{1}$ However, although international standards of measuring capital stocks slightly evolve, the applied methods differ from case to case quite substantially. ${ }^{2}$ As a result internationally comparable datasets are yet widely unavailable. While the OECD maintains a database of international capital stock data of its member countries, the data is a mixture of data collected from the national statistical offices and own estimations of the OECD. The OECD therefore recommends to be very careful in using the data for international comparisons. ${ }^{3}$ Very recently, capital stock data were included into the Penn World Tables Database (PWT 8.0). However, in an attempt to construct a database covering a large range of countries and long periods of time, again data from very different sources which are constructed with differing methods were merged. ${ }^{4}$ While this approach has its obvious merits, the high number of applied country-specific corrections and assumptions is not unproblematic.

The lack of internationally comparable capital stock data has been a major obstacle to empirical studies of the contribution of the capital stock to economic growth. In the absence of reliable capital stock data the scientific literature has often employed different proxies of capital accumulation. ${ }^{5}$ As a prominent example, BARRO (1991) and much of the related literature thereafter employed gross investment rates as a proxy for physical capital accumulation. While - in the absence of reliable measures of the capital stock - the use of these proxies is an acceptable alternative, the construction of capital stock data is surely the superior method. However, due to the fact that constructing capital stock data is a time-consuming task, most of the related literature has yet relied on the proxy approach.

Against the background that constructing adequate capital stock data is a complicate task it is not too surprising that only a few attempts have yet been made in the scientific literature to generate larger capital stock datasets. These few attempts all rely on the Perpetual Inventory Method, a methodology which is also most often used in statistical offices to construct capital stock data.

An early example is GrILICHES (1980) who constructs capital stock data from US 3-digit manufacturing industry data, provided by the Bureau of Labor Statistics for

1 A documentation of the system of capital stock measurement in the United States is reviewed in Bureau of Economic Analysis (2003), the Canadian method in Statistics CANADA (2001). For a description of the methods of measuring the German capital stock, see Schmalwasser and Schidlowski (2006).

2 SChreyer et al. (2011), p. 2.

3 SCHREYER et al. (2011).

4 For a documentation see InKLAAR and TIMMER (2013).

5 Benhabib and Spiegel (1994), p. 144. 
1959 to 1977 in order to study the effects of R\&D investments on output. In their study of the growth determinants of developing countries, NeHru and DHareswhar (1993) constructed capital stock data for 92 countries over the period of 1960 to 1990, thereby employing data from the WORLD BANK's Economic and Social Indicators Database. De la Fuente and Domenech (2000) study the effect of different measures of human capital in growth regressions and therefore construct capital stock data for OECD countries for the period of 1950 to 1997. In order to do so they use different OECD and IMF statistics.

Two more recent papers more directly focus on providing data for further analyses. KAMPS (2006) generated capital stock estimates for 22 OECD countries using investment data from the OECD Analytical Database. The resulting capital stock estimates (disaggregated for 3 different asset classes) range from 1960 to 2001 and can be downloaded from the internet page of the Kiel Institute for the World Economy. ${ }^{6}$ Derbyshire, Gardiner and Waights (2013) recently constructed regional capital stock estimates for the 27 EU countries on the NUTS II level. While the data come primarily from Eurostat, again several different sources have been used.

This paper contributes to the literature by constructing new estimates of the aggregate capital stock for a large sample of countries. In order to do so we propose a method which relies on the Perpetual Inventory Method. To avoid some of the disadvantages of earlier applications of the Perpetual Inventory Method we propose a unified approach which combines some elements of these applications. Moreover, we refrain completely from merging data from different databases in order to increase our sample size. Instead, we rely completely on investment data taken from the WORLD BANK's World Development Indicators Database. Doing so enables us estimating the aggregate capital stocks of 103 countries for the period of 1991 to 2010. Depending on data availability, the time series for many countries date back to as early as 1970 , thereby providing a rich database for comparative empirical analyses. The employed methodology also comes at the advantage that the dataset can easily be extended to more recent years as the data becomes available.

The paper is constructed as follows. Section 2 introduces the Perpetual Inventory Method. Section 3 gives an overview on earlier implementations of the Perpetual Inventory Method and discusses the relative advantages and disadvantages of these approaches. Based on this discussion section 4 proposes and explains a unified approach of constructing aggregate capital stock estimates using the Perpetual Inventory Method. Section 5 describes the employed data sources and gives an overview on the development of the number of sample countries over the sample period. Section 6 presents and discusses the results. Section 7 concludes.

6 See: http://www.ifw-kiel.de/academy/data-bases/netcap_e/database-on-capital-stocks-inoecd-countries/view?set_language=en. 


\section{Perpetual Inventory Method}

Almost all attempts of estimating capital stocks employ some variant of the Perpetual Inventory Method. Before studying these variants in more detail in the next section, we shall describe the basic approach.

The basic idea of the Perpetual Inventory Method is to interpret an economy`s capital stock as an inventory. The stock of inventory increases with capital formation (investments). Once, an investment entered an economy's inventory it remains there forever and provides services to the inventory owner. The quantity of services, the investment provides, is at its maximum directly after the investment has been made and decreases in the course of time. The amount by which the capital stock falls per period, is the depreciation rate. However, while the value of the investment decreases in the course of time, it never falls to zero. Thus, an investment principally has a perpetual use.

The net capital stock at the beginning of period $t, K_{t}$, can be written as a function of the net capital stock at the beginning of the previous period $t-1, K_{t-1}$, gross investment in the previous period, $I_{t-1}$, and consumption of fixed capital, $D_{t-1}$ :

$K_{t}=K_{t-1}+I_{t-1}-D_{t-1}$

Assuming geometric depreciation at a constant rate $\delta$, we can rewrite the capital stock as:

$K_{t}=(1-\delta) K_{t-1}+I_{t-1}$

Repeatedly substituting this equation for the capital stock at the beginning of period $t-1, K_{t-1}$, leads to:

$K_{t}=\sum_{i=0}^{\infty}(1-\delta)^{i} I_{t-(i+1)}$

Thus, the capital stock in period $t$ is a weighted sum of the history of capital stock investments. The weights result from the geometric depreciation function.

Obviously, calculating the actual capital stock in an accurate manner requires to have a complete time series of past investments. For many countries time series of investment data are available for at least a certain number of years. However, these time series typically cover only the (very) recent part of the capital stock history. Given the available time series of investments is incomplete, we nevertheless can calculate the current capital stock $K_{t}$ accurately whenever the initial capital stock at the beginning of the investment time series, $\bar{K}$, is known:

$K_{t}=(1-\delta)^{t-1} \bar{K}+\sum_{i=0}^{t-1}(1-\delta)^{i} I_{t-(i+1)}$

Thus, in order to be able to apply the Perpetual Inventory Method to calculate the current capital stock, we need (i) a time series of investment data, (ii) information on the initial capital stock at the time when the investment time series starts and (iii) information on the rate of depreciation of the existing capital stock. 


\section{Implementations of the Perpetual Inventory Method}

Over the years, various researchers have used the Perpetual Inventory Method to construct capital stock data. While the basic technique is quite similar and follows the idea outlined in the previous section, the concrete implementation of the Perpetual Inventory Method differs to some extent. Methodological differences especially exist with respect to the method of estimating the initial capital stock. In this section we give an overview on the most important approaches employed in the literature. We thereby focus on the three different approaches used most frequently.

\subsection{Steady State Approach}

A first approach of estimating the initial capital stock is based on HARBERGER (1978). This approach employs neoclassical growth theory and relies on the assumption that the economy under consideration is in its steady state. As a consequence of this assumption, output grows at the same rate as the capital stock, i.e.:

$g_{G D P}=g_{K}=\frac{K_{t}-K_{t-1}}{K_{t-1}}=\frac{I_{t}}{K_{t-1}}-\delta$.

Solving this equation for the stock of capital in period $t-1$ leads to:

$K_{t-1}=\frac{I_{t}}{g_{G D P}+\delta}$

Thus, if in fact an economy is in its equilibrium, information on the current level of investments, the depreciation rate and the growth rate of output are sufficient to calculate the capital stock in the preceding period.

An obvious problem of the Steady State Approach is that the estimate of the initial capital stock depends crucially on the investments and the growth rate of output in a single year. While this is unproblematic if the economy under consideration is in fact in equilibrium, a short-term investment shock in the first period of the available time-series of investments would lead to a strongly biased initial capital stock estimate.

Aware of this problem, HARBERGER (1978) uses three-year averages instead of a single year to generate more stable and reliable capital stock estimates. In a later application of the Steady State Approach, NeHru and DHARESHwar (1993) proposed an alternative procedure. In order to generate a reliable initial value of the investment time series the authors regress the time series of log investments on time and then use the fitted value for the first period to calculate the initial capital stock.

\subsection{Disequilibrium Approach}

A second approach of estimating the initial capital stock goes back to GRILICHES (1980) and was used and further refined by DE LA FuENTE and DoMENECH (2000). 
Similar as the Steady State Approach, the reasoning of this method bases on the neoclassical growth model. As outlined earlier, the capital stock can be written as

$K_{t-1}=\frac{I_{t}}{g_{G D P}+\delta}=\frac{I_{t}}{g_{K}+\delta}$.

De la Fuente and Domenech (2000) argue that the growth rate of the capital stock can be approximated by the growth rate of investments, i.e.

$K_{t-1} \approx \frac{I_{t}}{g_{I}+\delta}$

However, different from the approaches in the tradition of HARBERGER (1978), DE LA Fuente and Domenech (2000) argue that an economy is typically not in its longterm equilibrium. From their point of view it is more reasonable to assume that economies are most of the time on their adjustment path towards equilibrium. Throughout this adjustment process investment and capital accumulation tend to follow a systematic pattern. DE LA FUENTE and DOMENECH (2000) therefore propose to use data for longer time-periods to estimate the initial capital stock. More precisely, they use a Hodrick-Prescott-Filter ${ }^{7}$ to smooth the time-series of investment data. Since the HP-Filter is known to display anomalities at endpoints they drop the first 5 annual observations of the smoothed investment time-series. As proxy for the growth rate of investments they then use the average of the first ten observations.

\subsection{Synthetic Time Series Approach}

A third procedure of estimating the initial capital stock goes back to JACOB, SHARmA and GrABOwSKY (1997) and was further refined by KAMPS (2006). The idea behind this approach is to construct an artificial, historical time series of investments. This time series, together with an assumption on capital depreciation rates is then used to calculate the initial capital stock.

The applied procedure starts out from the first observation of investments which is available $\left(I_{t}\right)$. For reasons of simplicity, KAMPS (2006) assumes a constant annual growth rate of investments of 4 percent $\left(w_{I}=0.04\right)$, which coincides with the average growth rate of investments in the United States from 1960 to 2001. Applying this assumption, the level of investments in an arbitrarily chosen base period $t_{0}$ can then be calculated as:

$I_{0}=\frac{I_{t}}{e^{w_{I} \cdot\left(t-t_{0}\right)}}$

Using this formula, an artificial time-series of investments can be constructed. ${ }^{8}$ This time series is then used to calculate the initial capital stock for period

Hodrick and Prescott (1997).

KAMPs (2006) does not adjust the resulting time series for catastrophic losses from e.g. natural disasters or wars. He argues that countries experiencing catastrophic losses typically recovered quickly, thereby returning to the long-term trend. 
$t-1 .{ }^{9}$ However, in order to be able to do so, an assumption on the prevailing rate of capital depreciation has to be made. KAMPS (2006), basing his assumptions on data of the U.S. Bureau of ECONOMIC AnALYsis, employs time-varying depreciation profiles, thereby distinguishing between three different subgroups of investments (private residential, private non-residential, public). For the synthetic time series, covering the period from 1860 to 1960 , KAMPs (2006) assumes a constant depreciation rate of 4.25 percent for nonresidential assets, 1.5 percent for residential assets and 2.5 percent for government assets. For the subsequent years 1961 to 2001 he assumes the rate for private nonresidential assets to increase gradually from 4.25 percent to 8.5 percent, for government assets from 2.5 to 4.0 percent, thereby applying the formula

$\delta_{t}^{j}=\delta_{\min }^{j}\left(\left(\frac{\delta_{\max }^{j}}{\delta_{\min }^{j}}\right)^{\frac{1}{4 I}}\right)^{t-2001+41}$

The depreciation rate for private residential assets is held constant at 1.5 percent. Figure 1 shows the earlier described capital depreciation scheme applied by KAMPS (2006).

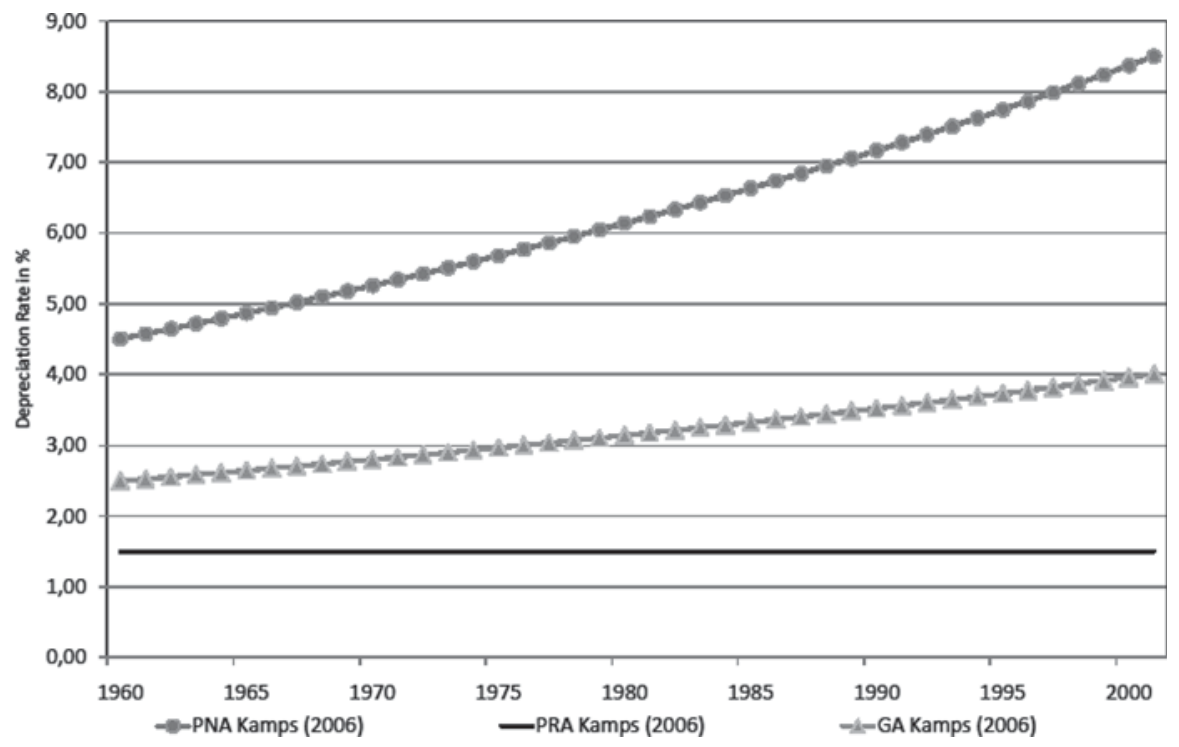

Figure 1: Depreciation rates of gross fixed asset categories 1960-2001 according to KAMPS (2006)

9 Obviously, this procedure neglects the capital stock which was accumulated before the chosen base period. However, provided the base period is chosen early enough, the capital stock in the base period can be neglected since capital depreciation led to an almost complete erosion of this initial capital stock. 


\subsection{Weaknesses of the approaches}

As outlined in the previous subsection, the most important difference between the Steady State Approach, the Disequilibrium Approach and the Synthetic Time Series Approach is the applied procedure to construct the initial capital stock. As the initial capital stock becomes more and more irrelevant in the course of time due to capital depreciation, the capital stock time series derived from applying the different procedures differ most strongly in the early years. As the true capital stock cannot be observed directly, there is little possibility to study which of the described implementations of the Perpetual Inventory Method delivers the best results. We therefore refrain from judging the three methods on the basis of the generated time series of capital stock data. Instead it seems to be useful to focus on conceptual issues.

All three described approaches of estimating the initial capital stock have their specific drawbacks. The Steady State Approach might lead to rather implausible results whenever the (average) growth rate of a country turns out to be negative in the period(s) which are used to calculate the initial capital stock. Whenever the absolute value of the growth rate is considerably larger than the rate of depreciation, the term $g_{G D P}+\delta$ becomes strongly negative. As a consequence, the estimate of the initial capital stock also becomes negative, which is implausible. Whenever the growth rate of GDP is negative and its absolute value is (almost) equal to the rate of capital depreciation, i.e. $g_{G D P}+\approx 0$, the estimated capital stock becomes either implausibly large or highly negative, i.e.

$$
\lim _{g_{G D P}+\delta_{t} \rightarrow 0} \frac{I_{t}}{g_{G D P}+\delta}=+/-\infty
$$

Both results are again highly implausible.

When using the Disequilibrium Approach some filter is necessary to extract information on the likely adjustment path of investments. However, conventional filters like the HP-Filter typically deliver inefficient results at the start and endpoints of a sample. ${ }^{10}$ Thus, when fitting the investments series, the first observations are typically dropped, ${ }^{11}$ thereby leading to a loss of information.

In the Synthetic Time Series Approach the initial capital stock depends critically on the first and thus a single observation of the investment time series. Whenever this observations turns out to be an outlier, the initial capital stock can be severely overor underestimated.

In order to prevent these problems from occurring one might consider to combine the three described approaches, thereby using their relative advantages and avoiding their relative drawbacks. In the subsequent section we develop a proposal for a such a combination method.

\footnotetext{
10 See e.g. Mise, Kim and Newbold (2005).

11 As an example Domenech and DE LA Fuente (2000) drop the first 5 data points.
} 


\section{A Unified Approach}

As almost all approaches of estimating capital stock data even our proposal of a combination approach makes use of the Perpetual Inventory Method. In general, our proposal follows the procedure employed by DE LA FuENTE and DOMENECH (2000). We thus follow the idea to calculate the initial capital stock $K_{t 0}$ from the investments $I_{t 1}$, the long-term growth rate of Investments $g_{I}$ and the rate of capital depreciation $\delta$ :

$K_{t 0} \approx \frac{I_{t 1}}{g_{I}+\delta}$

However, we deviate from the procedure of DE LA FUENTE and DOMENECH (2000) in three respects.

First, we do not use a filter to estimate the initial investment value. In order not to lose any investment information we instead follow the idea of NEHRU and DHARESHWAR (1993) to derive the initial investment value $I_{t 1}$ from a regression approach. We therefore use the whole time series of investments, ranging from time $t_{2}$ to $T$. In order to do so, we regress the time series of $\log$ investments $\ln \left(I_{i, t}\right)$ for any country $i$ on time $t$. Thus, we estimate the equation

$\ln I_{i, t}=\alpha_{i}+\beta_{i} \cdot t+\varepsilon_{i, t}$

using the OLS method. In a next step we calculate the fitted value for period $t_{1}$, thereby using the estimated parameters $\alpha_{i}$ and $\beta_{i}$, i.e.

$\ln \widehat{\left(I_{t 1}\right)}=\alpha_{i}+\beta_{i} \cdot t_{l}$.

After transforming the fitted value using the exponential function we end up with a time series of investments ranging from $t_{1}$ to $T$. We then use the first (and thus the fitted) value of this time series to calculate the initial capital stock in period $t_{0}$.

Second, we deviate from DE LA Fuente and Domenech (2000) in the way of calculating the growth rate of investments $g_{I}$. Instead of using the mean of the investment time series (or subsamples of the series) we employ the estimated parameter of $\beta_{i}$ from the regression approach as measure of trend investment growth.

Third, we do not use a constant rate of depreciation in our approach, neither for the calculation of the initial capital stock nor for the further construction of the time series of capital stocks using the Perpetual Inventory Method. Instead we follow the idea of KAMPS (2006) to use time-varying depreciation schemes, which seem to be the more plausible variant.

Since the capital depreciation schemes proposed by KAMPS (2006) end in 2000 it is impossible to simply apply them to our data directly. The time series would have to be extended in a plausible way. However, since there is no obvious way of prolonging the time-series we opt for a slightly different approach. KAMPS (2006) bases his assumptions on capital depreciation schemes on US data, provided by the U.S. Bureau of Economic Analysis. We follow this procedure and base our assumptions on the same database, although the now larger number of available observa- 
tions. However, instead of defining a synthetic mathematical function which delivers a similar pattern as the observed values, we estimate the depreciation rates for the period of 1950 to 2011 in three separate linear OLS regressions (private non-residential, private residential and government fixed assets). The estimation results are summarized in table 1 .

Table 1: Estimation results depreciation rates of private non-residential, private residential and government fixed assets, United States, 1950-2011

\begin{tabular}{|lccc|}
\hline & $\begin{array}{c}\text { Private Non-Residen- } \\
\text { tial Fixed Assets }\end{array}$ & $\begin{array}{c}\text { Private Residential } \\
\text { Fixed Assets }\end{array}$ & $\begin{array}{c}\text { Government Fixed } \\
\text { Assets }\end{array}$ \\
\hline Constant & $-66.6852^{* * *}$ & $-3.9470^{* * *}$ & $23.6991^{* * *}$ \\
& $(3.0571)$ & $(0.5286)$ & $(4.0462)$ \\
Depreciation Rate & $0.0370^{* * *}$ & $0.0003^{* * *}$ & $-0.0102^{* * *}$ \\
& $(0.002)$ & $(0.0003)$ & $(0.0020)$ \\
Adj. $\mathrm{R}^{2}$ & 0.90 & 0.63 & 0.28 \\
F-Statistic & $575.79^{* * *}$ & $105.37^{* * *}$ & $25.01^{* * *}$ \\
& & & \\
\hline
\end{tabular}

$* * *$ : significant on the $99 \%$ confidence level, $* *$ : significant on the $95 \%$ confidence level, *: significant on the $90 \%$ confidence level; values in brackets are standard errors

In figure 2 we show the actual time series of depreciation rates, the estimated depreciation rates as they result from the fitted values of the regression and the referring assumptions used by KAMPS (2006) for every fixed asset class. While for the depreciation rate of private residential fixed assets (PRA) the results are quite similar to the assumptions of KAMPS (2006), our findings for government fixed assets (GA) and private non-residential fixed assets (PNA) somewhat differ. Obviously, the occurring differences cannot be completely explained by the differing sample periods.

According to our findings, the depreciation rate of private non-residential fixed assets increases from roughly $5.5 \%$ in 1950 to $7.8 \%$ in 2011 . Thus, while we also find an increase in the depreciation rate of private non-residential fixed assets, this growth rate is somewhat lower as assumed in KAMPS (2006), who assumes the depreciation rate to increase from $4.5 \%$ to $8.5 \%$ in between 1960 and 2001. While KAMPS (2006) assumes a constant depreciation rate of $1.5 \%$ for private residential fixed assets, we find the depreciation rate to increase slightly from $1.4 \%$ to $1.6 \%$. However, the difference is negligible. The most obvious difference occurs for government fixed assets. While KAMPS (2006) assumes an increase of the depreciation rate from 2.5\% to $4 \%$ over his sample period, we find the depreciation rate of government assets to decrease from $3.8 \%$ in 1950 to $3.2 \%$ in 2011 . As our estimation bases on more and more actual data, we in the following apply the fitted values as prevailing deprecia- 
tion rates. As we have no comparable data for the other sample countries we follow KAMPS (2006) in assuming that these depreciation rates apply to all countries in the sample. $^{12}$

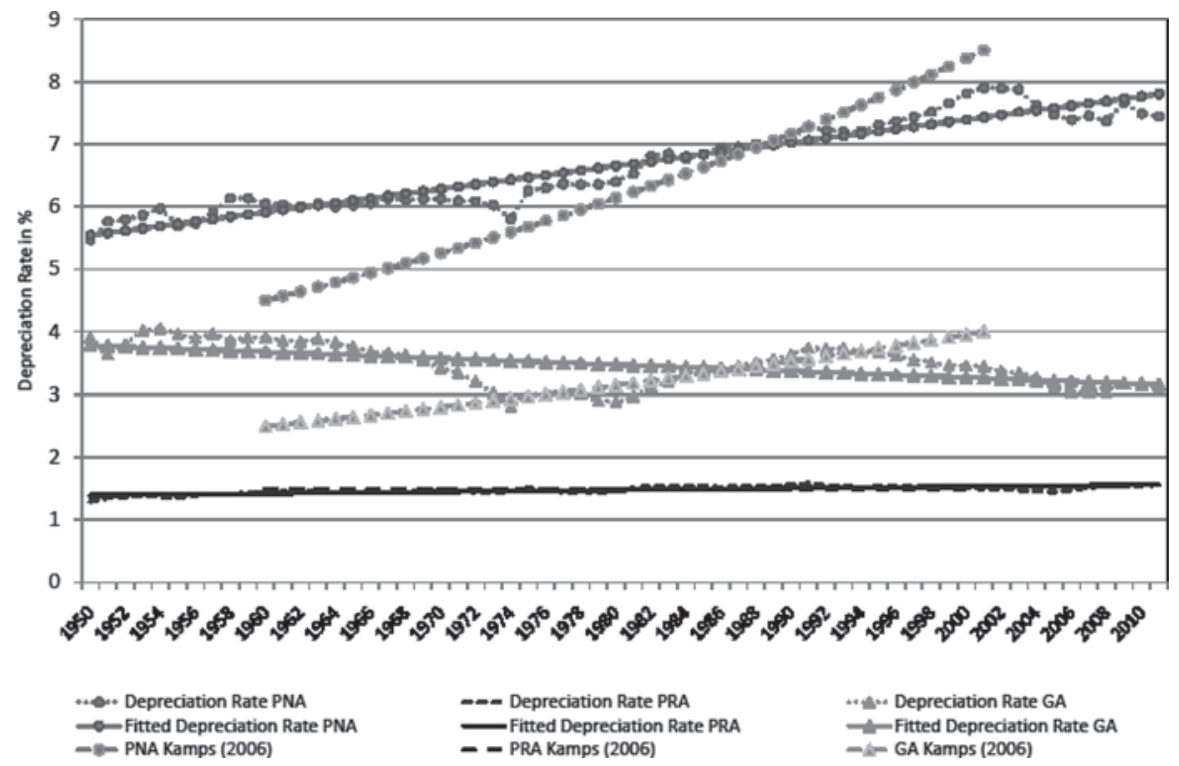

Figure 2: Various depreciation rates of gross fixed asset categories 1950-2010

Before the derived capital depreciation rates can be used in our empirical approach they have to be aggregated in a suitable manner. In order to construct an adequate aggregate depreciation rate we calculate a weighted average of the three depreciation rates of private residential, private non-residential and government fixed assets. As weighting factor we use the average mix of all 22 OECD countries in the OECD Economic Outlook database. ${ }^{13}$ The resulting depreciation rate, which is shown in figure 3 , is then applied to all sample countries.

12 The lack of comparable data for the other sample countries is also the primary reason why we rely on the fitted rather than the originial values of the depreciation rates. Using the fitted values at least removes U.S. specific variance in the depreciation rates as they might result from business cycle fluctuations.

13 Since our time series of depreciation rate has to date back to earlier years than 1970 and thus to years for which nor disaggregate data are available, we decided to use the data of 1970 for these years. For all years after 1970 the actual weighting factors are used. 


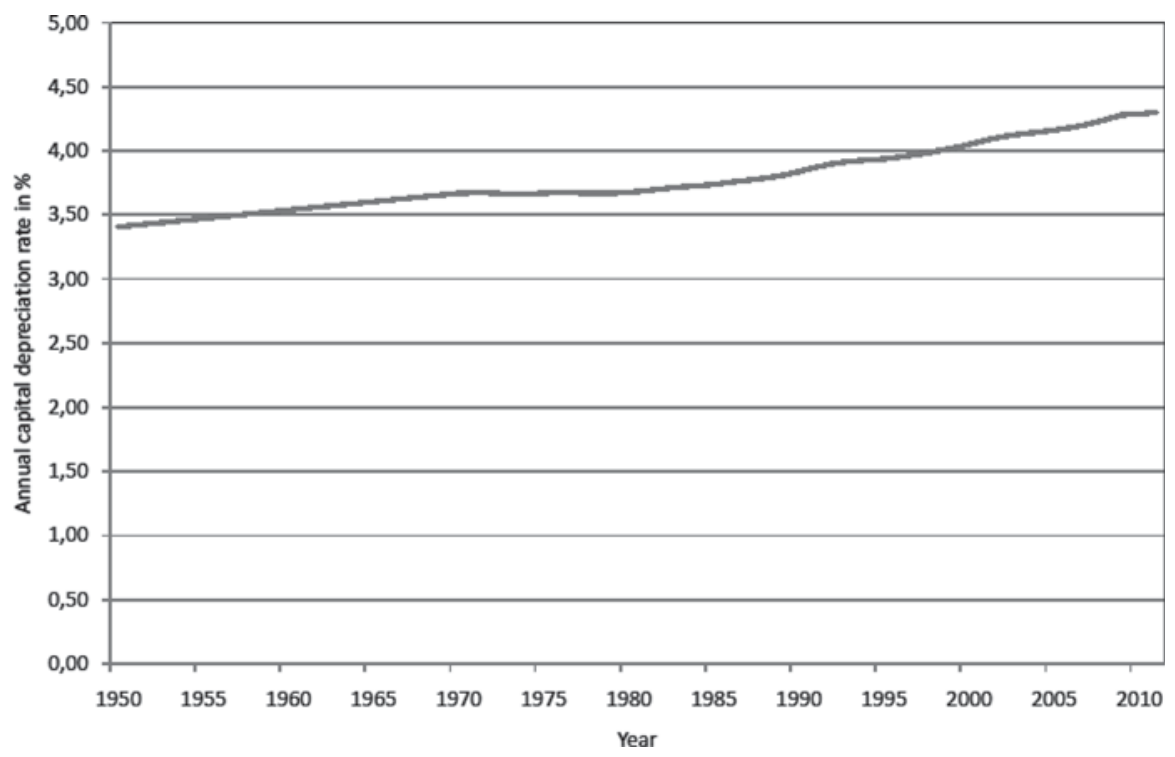

Figure 3: Assumed aggregate depreciation rate of gross fixed assets, 1950-2010

\section{Sample countries and data}

Our aim is to construct time series of capital stock data for a large sample of countries without having to rely country-specific and thus likely incomparable data sources. Instead of using data from the OECD database, which allow to differentiate between three classes of capital investment but are only available for 22 OECD countries, we rely on aggregate investment data provided by the WORLD BANK in the World Development Indicators (WDI) database. ${ }^{14}$ The investment data includes land improvements (fences, ditches, drains, and so on), plant, machinery, and equipment purchases; the construction of roads, railways, and the like, including schools, offices, hospitals, private residential dwellings and commercial and industrial buildings. According to the 1993 SNA, net acquisitions of valuables are also considered as capital formation. Data are in constant 2000 USD. ${ }^{15}$

While the WDI database of the WORLD BANK contains aggregate investment data on a large number of countries, the starting dates of the data differ heavily from

14 We used gross fixed capital formation data with the code: NE.GDI.FTOT.KD on 03/20/ 2012 from the WDI database.

15 For a description of the data see the website of the World BANK: HTtP://DATABANK. WORLDBANK.ORG/DDP/VIEWSOURCENOTES. 
country to country. Figure 4 illustrates aggregate data availability. For 30 countries, the investment time series start out as early as in 1960. Major increases in the number of countries, for which data is available are 1965 (8 countries), 1970 (16 countries), 1980 ( 7 countries) and 1990 (14 countries). The 14 countries added in 1990 are primarily East European transformation countries. Since 1991 the number of countries, for which data is available, amounts constantly to 103. A table with more detailed information can be found in the appendix.

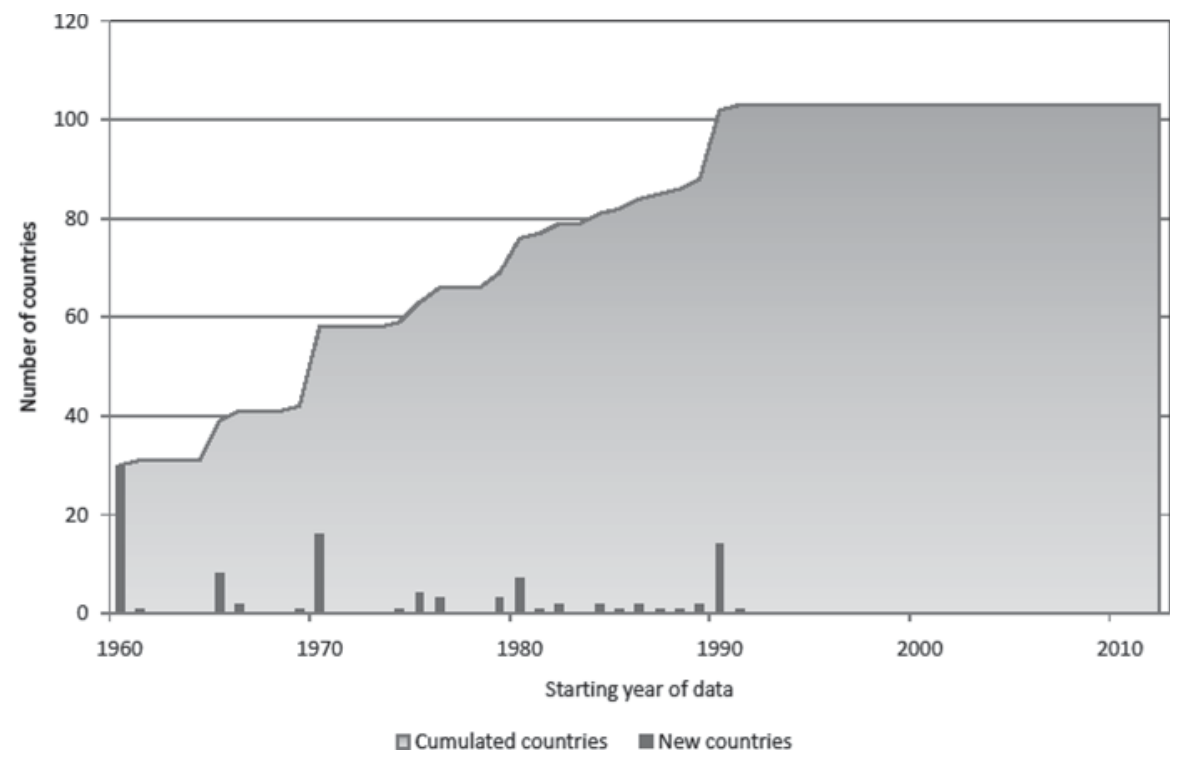

Figure 4: Number of sample countries over time in the WDI database

The country sample consists of countries with quite different levels of development. According to the WORLD BANK classification four types of countries are distinguished: low, lower middle, upper middle and high income countries. ${ }^{16}$ As figure 5 reveals, the country sample consists of countries of all four classes, although (due to data availability reasons) especially the low income countries are somewhat underand especially the high income countries overrepresented.

16 We classify the countries by income groups: Economies are divided according to $2011 \mathrm{GNI}$ per capita, calculated using the WORLD BANK Atlas method. The groups are: low income (USD 1025 or less); lower middle income (USD 1026-USD 4035); upper middle income (USD 4036-USD 12475); and high income (USD 12476 or more). The WorLd BANK classification can be found on http://data.worldbank.org/about/country-classifications. 


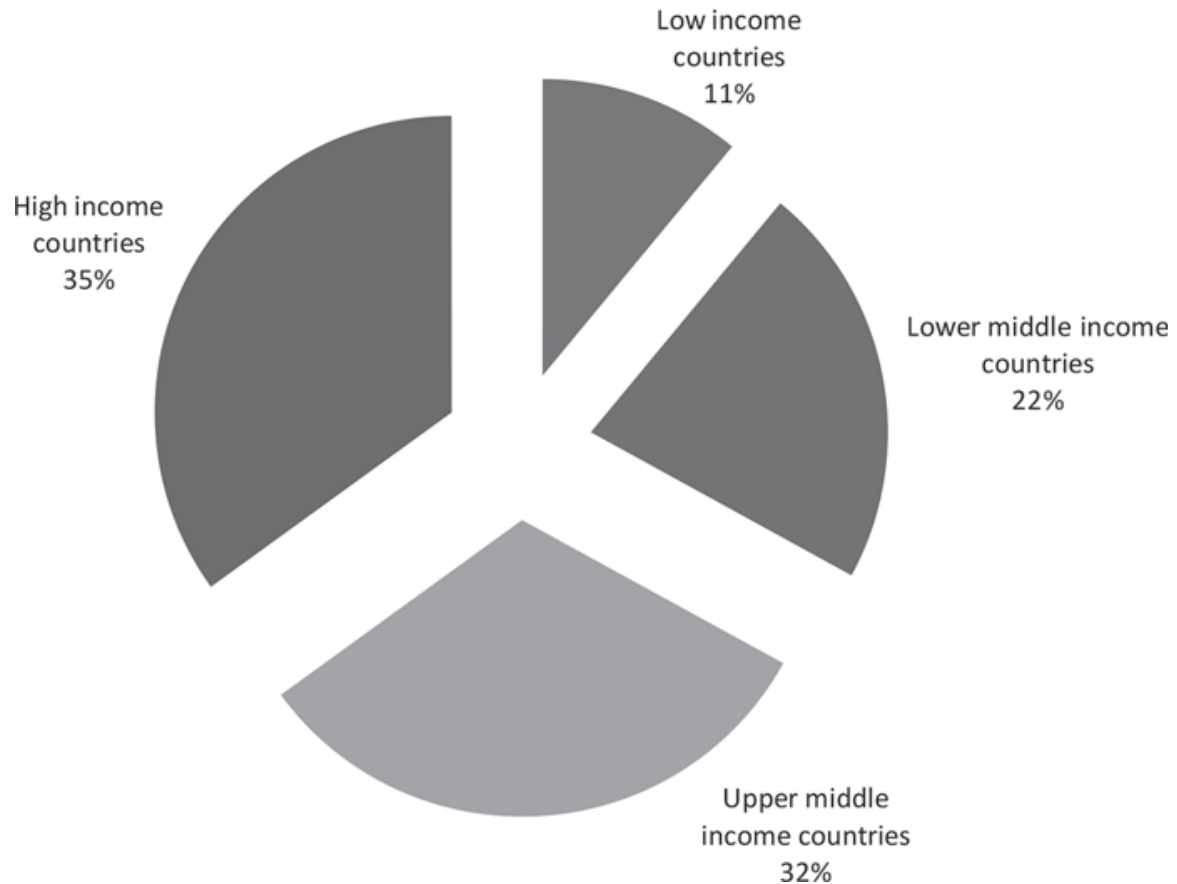

Figure 5: Country sample by WORLD BANK classification

\section{Capital stock estimation results under the Unified Approach}

In the following we give an overview on the most important results of our aggregate capital stock estimations. ${ }^{17}$ Due to space restrictions we concentrate on reporting the estimation results for the absolute aggregate capital stocks, capital intensities (capital per worker), and capital coefficients (capital per unit of GDP). We also study the development of dispersion of these measures over time. Some of the presented graphs necessarily concentrate on subgroups of all sample countries. However, more detailed results are summarized in the appendix.

\subsection{Aggregate capital stocks}

In figure 6 we show a map visualizing the estimated aggregate stocks for 2010 . Somewhat unsurprisingly, the countries with the most inhabitants tend to have also

17 The complete dataset can be downloaded from the authors' internet page. For further requests contact the corresponding author. 
the highest capital stocks, at least whenever they are at least upper middle income countries. In figure 7 we show the 20 countries with the highest aggregate capital stocks in 2010. In fact, only three countries with less than 20 million inhabitants are among the 20 countries with the largest capital stocks: the Netherlands, Switzerland and Belgium. The United States and Japan turn out to have by far the highest capital stocks. While China makes it to the third place of the ranking, its capital stock is only slightly higher than one quarter of the capital stock of the United States. Germany follows closely behind China. On the fourth, fifth and sixth place we find France, the United Kingdom and Italy with only slightly differing capital stocks. The next group of countries with similar aggregate capital stocks consists of Spain, Canada, South Korea, Brazil, India, Russia, Mexico and Australia. The final group is headed by the Netherlands and includes Switzerland, Argentina, Turkey and Belgium.

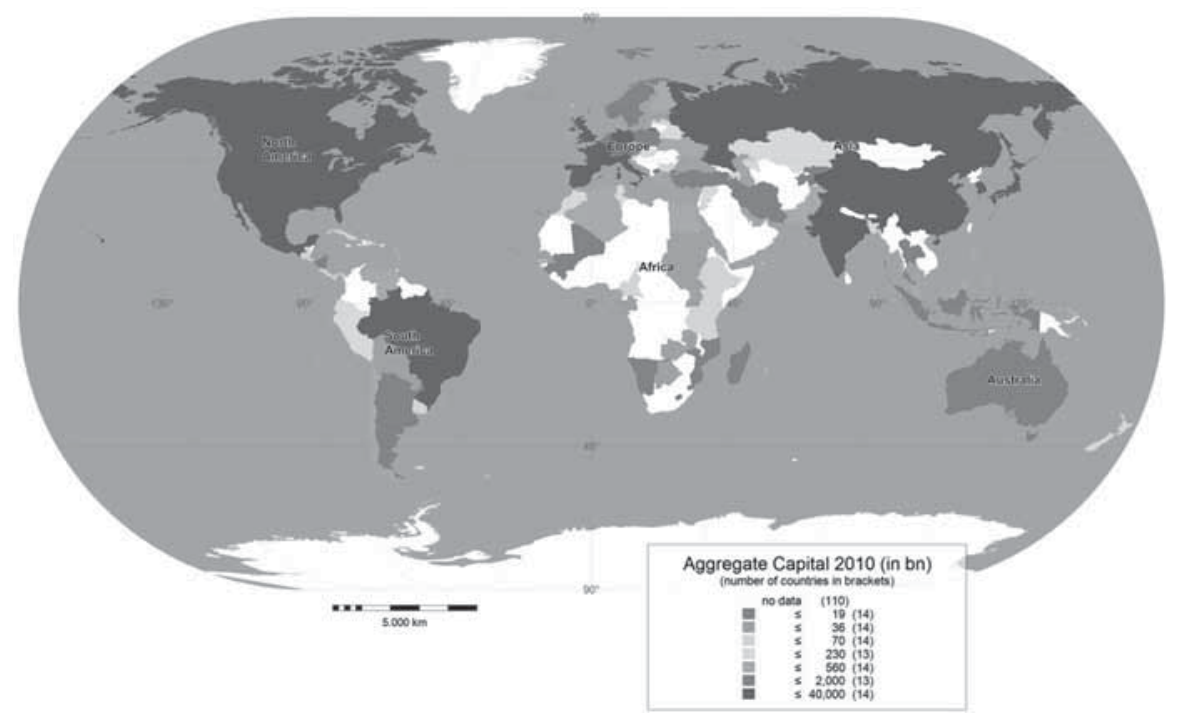

Figure 6: Estimated aggregate capital stocks 2010, 103 countries (in bn. USD of 2000)

In Figure 8 we show a world map reporting the annual growth rates of the aggregate capital stock in the sample countries in between 1991 and $2010 .{ }^{18}$ It is easy to see that capital growth varies significantly between our sample countries. In seven sample

18 We chose the period of 1991 to 2010 because for this period data for all 103 countries in our sample are available. 
countries, the capital stock decreased throughout the last two decades. Among these countries are a few African countries such as Guinea $(-1.48 \%)$, Zambia $(-1.24 \%)$, Swaziland $(-0.48 \%)$ and Gabon $(-0.46 \%)$, but also Cuba $(-1.55 \%)$. Russia's aggregate capital stock also decreased over the last two decades by almost one percent per year. The worst development of the aggregate capital stock of all sample countries occurred in the Ukraine $(-1.94 \%)$.

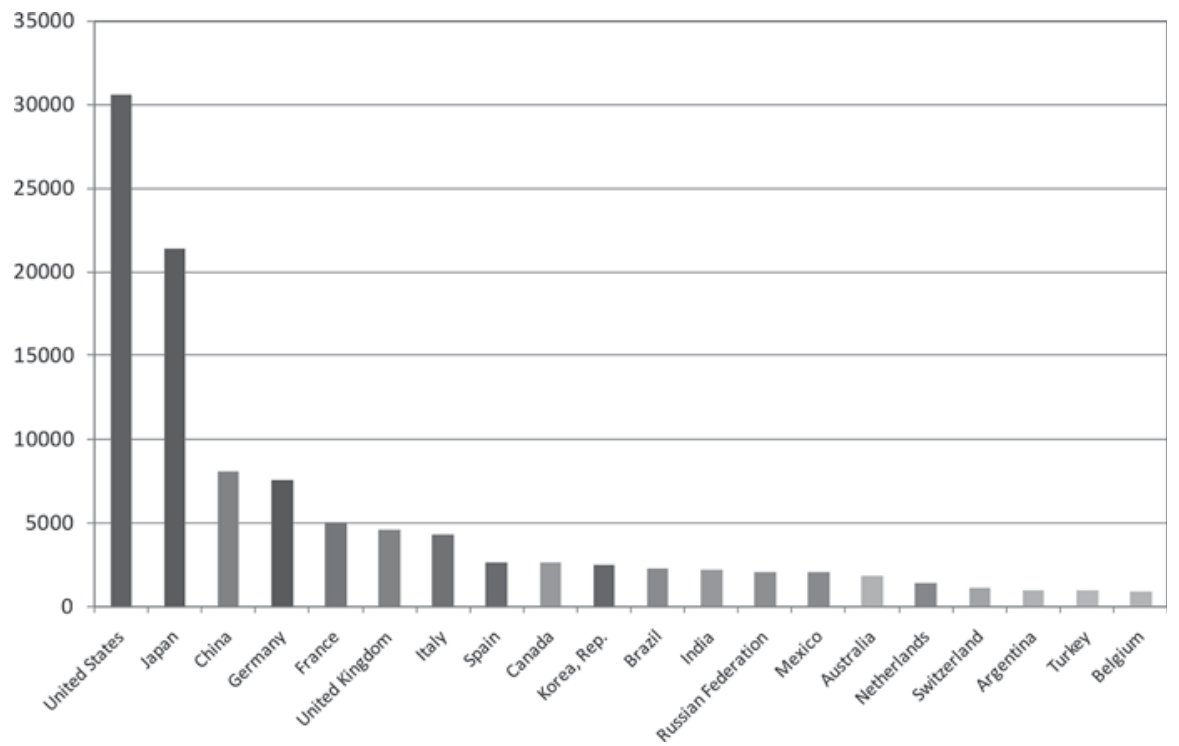

Figure 7: Sample countries with highest estimated aggregate capital stock 2010 (in bn. USD of 2000)

Figure 9 reports the 20 sample countries with the highest aggregate capital stocks growth rates in the last two decades. Azerbaijan $(19,0 \%)$ realized the highest annual growth rate of the capital stock throughout the period of 1991-2010. With an annual growth rate of $11,0 \%$ China follows on the second place. The other 18 countries realized annual growth rates of the aggregate capital stock in between $8.2 \%$ and $5.8 \%$. This group of countries includes 6 African countries (Sudan, Uganda, Mozambique, Botswana, Madagascar and Tanzania), besides Azerbaijan 3 additional transition countries (Slovenia, Latvia and Poland) and besides China 5 additional East-Asian countries (Republic of Korea, India, Bangladesh, Macao and Malaysia). The remaining countries come from Middle and South-America: The Bahamas, Chile, the Dominican Republic and Panama.

Figure 10 shows the development of the aggregate capital stock for the 10 countries with the highest capital stock in 2010 over the sample period. For a long time 
Japan's capital stock was only slightly lower than the one of the United States. In the late 1990s Japan almost closed the remaining gap. However, since then Japan's capital stock development somewhat flattened, while the capital stock of the United States continued to increase considerably. For almost the whole sample period, Germany held the third position in the absolute capital stock. However, in the course of time the gap to the United States and Japan grew larger and larger. According to our estimations China overtook Germany recently in terms of the absolute capital stock in 2009 and now holds the third place. In general, China's capital stock experienced a remarkable development. While in 1970 only the Korea Republic had a lower capital stock than China (among the 2010 top ten countries), since then China overtook all other countries except Japan and the United States. The only additional change in positions occurred in 2004 when the United Kingdom's capital stock grew larger than the one of Italy.

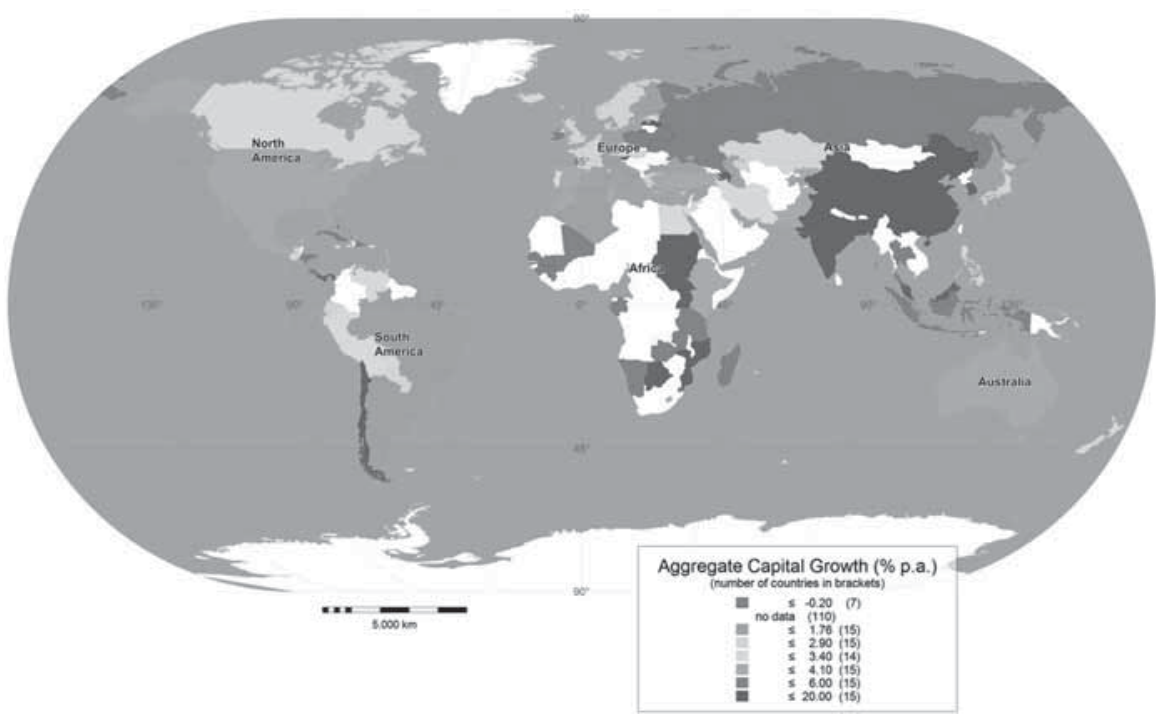

Figure 8: Growth of estimated aggregate capital stocks 1991-2010, 103 countries (in $\%$ p.a.)

Over the period of 1991-2010 the average aggregate capital stock of the 103 sample countries almost doubled from 676 bn. USD in 1991 to 1194 bn. USD in 2010. However, this increase in the mean level was not accompanied by a convergence of the capital stocks. Over the same horizon, the standard deviation of the aggregate capital stocks rose strongly from 2188 bn. USD in 1991 to 3882 bn. USD in 2010. 


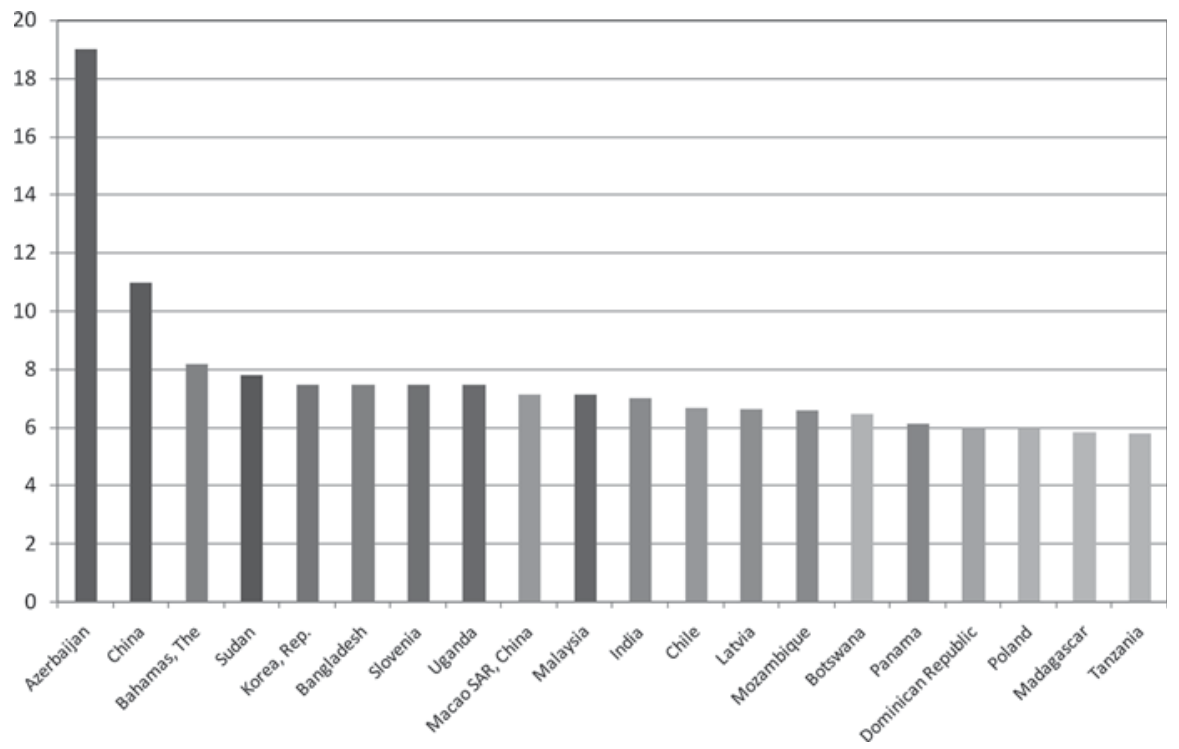

Figure 9: Sample countries with highest estimated growth rate of capital stock 19912010 (in \% p.a.)

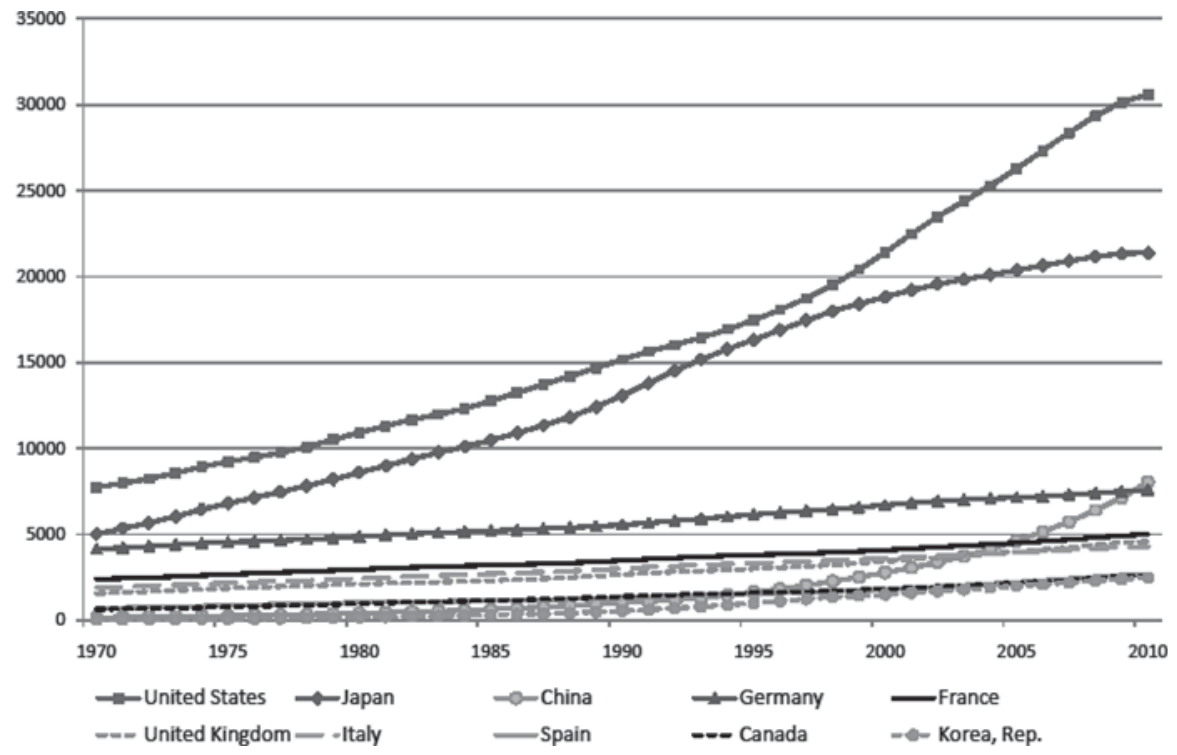

Figure 10: Gross fixed assets 1970-2010, 10 countries with largest aggregate capital stocks in 2010 (in bn. USD of 2000) 


\subsection{Capital intensity}

While absolute aggregate capital stock data are often useful for empirical analyses one might argue that the capital stock available per worker, i.e. capital intensity, is at least from some perspectives - the more interesting variable. High capital intensities indicate that the amount of physical capital available per worker in the production process is also high.

In figure 11 we show a world map reporting capital intensities for the year 2010 . It is easily visible that the ranking for this indicator is quite different from those reported in section 6.1. Especially China, but also India and to some lower extent also Brazil and Russia do not perform very well in terms of capital intensity. On the other hand comparatively small but highly developed countries like the Scandinavian countries, Ireland, Austria, Luxemburg and even the Bahamas appear among the 20 countries with the highest capital intensities.

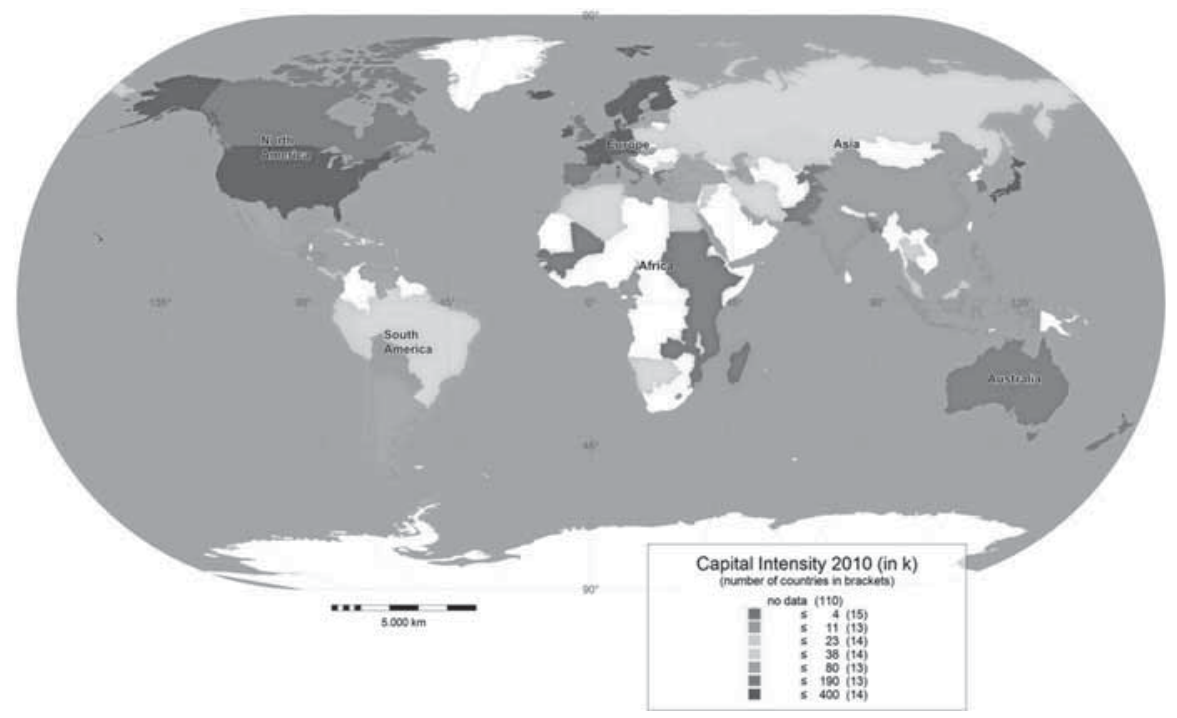

Figure 11: Gross fixed assets per worker 2010 (in USD of 2000)

As figure 12 reveals, Japan turns out to be the country with the highest capital intensity, however, with only a small advantage before Luxemburg. Even Switzerland and Norway exhibit considerably higher capital intensity than the United States. Almost on the same level as the United States we find countries like Belgium, China, Denmark, Iceland, Austria, Ireland, Finland, Germany, France and Italy. Lagging slightly behind that large group, the top 20 are completed by the Netherlands, Australia, the United Kingdom and the Bahamas. 


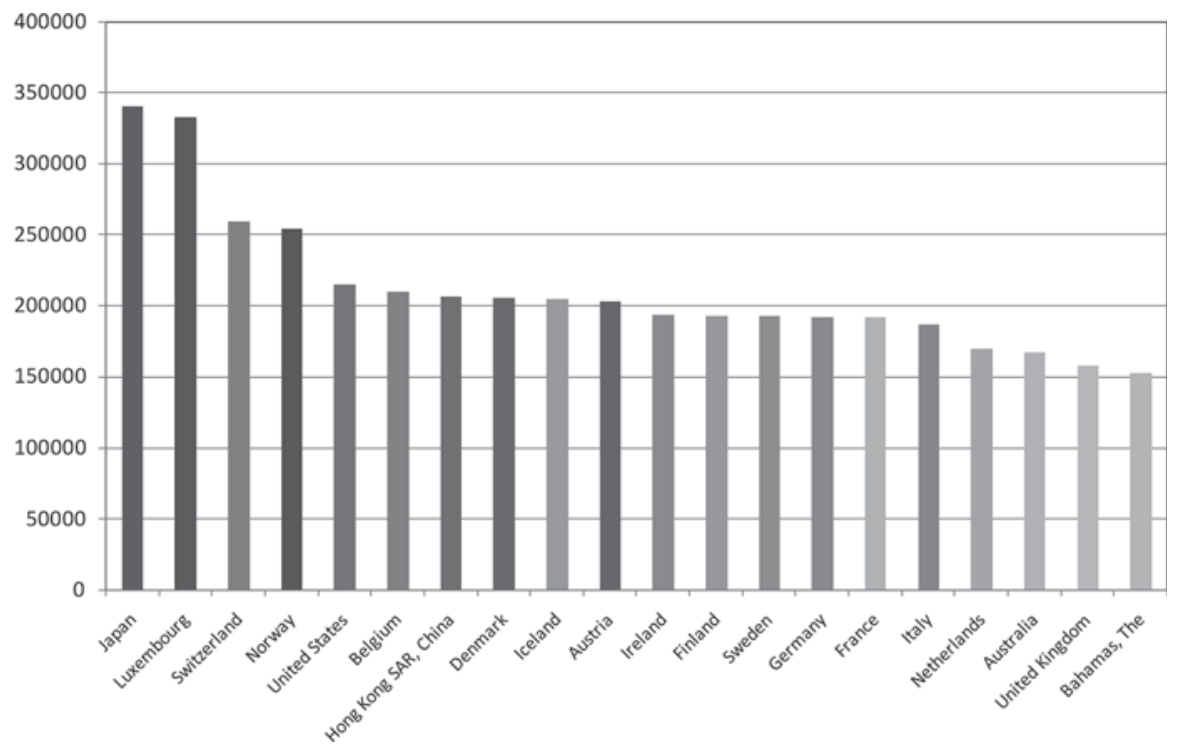

Figure 12: Countries with highest capital intensities in 2010 (in USD of 2000)

Over the period from 1991 to 2010, average capital intensity in our sample countries rose from 50461 to 67606 . However, again the dispersion within the sample increased. While the standard deviation of capital intensities in 1991 was 61844 , it rose to 81634 in 2010 . Thus, we observe no convergence of capital intensities in the sample countries.

\subsection{Capital coefficients}

It is also an interesting question, how much capital a country needs to generate the current output. In order to study this question, we calculate capital coefficients for all countries in our country sample. The capital coefficient is simply the amount of capital divided by the gross domestic product. The capital coefficient informs how much capital is needed to generate one unit of output. Figure 13 shows a world map with capital coefficients. Figure 14 delivers an overview on the 20 countries with the highest capital coefficients.

The country with the by far highest capital coefficient is the Ukraine (8.07), followed by Gabon (5.68), Lesotho (5.01), Russia (4.99), Swaziland (4.71), Estonia (4.37), Japan (4.20) and Brunei/Darussalam (4.02). The following group of countries consists of the Bahamas, Portugal, Iran, Hungary, Spain, Austria, Italy, Switzerland, the Czech Republic, Germany, Ecuador and Bulgaria with quite homogenous capital coefficients in between 3.92 and 3.57. The countries with the lowest capital coefficients are Tajikistan (1.72), the Dominican Republic (1.65), Macao (1.46) and Sudan (1.22). 


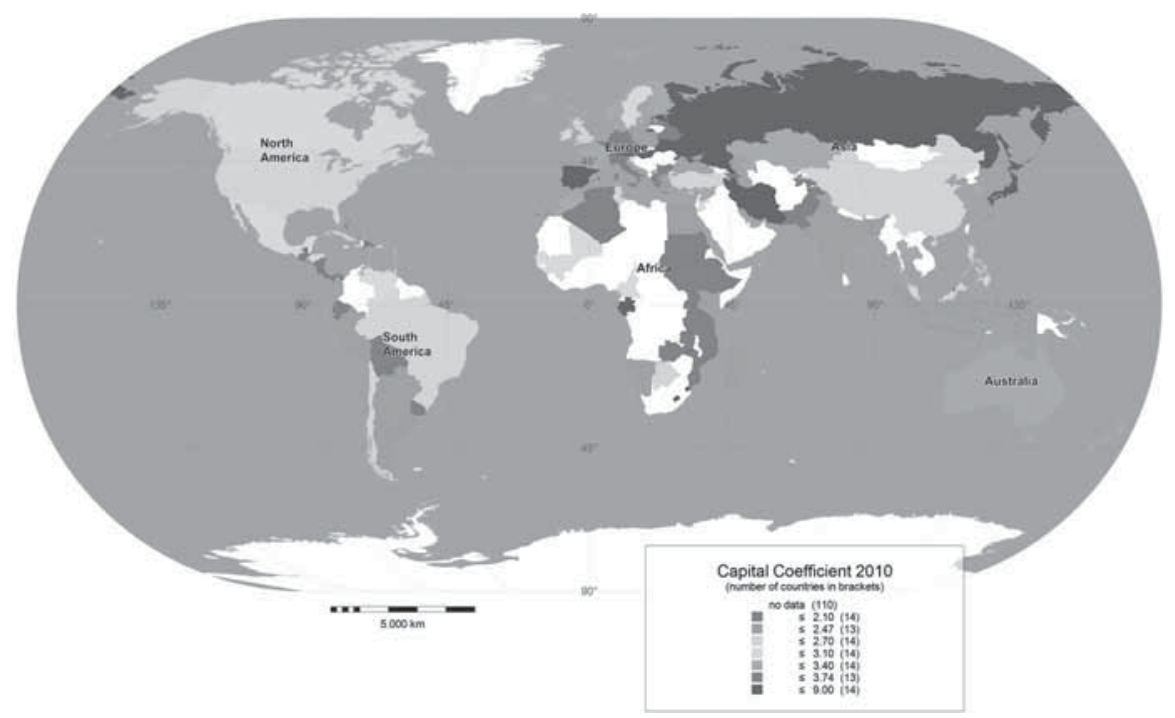

Figure 13: Capital coefficients 2010 (based on USD of 2000)

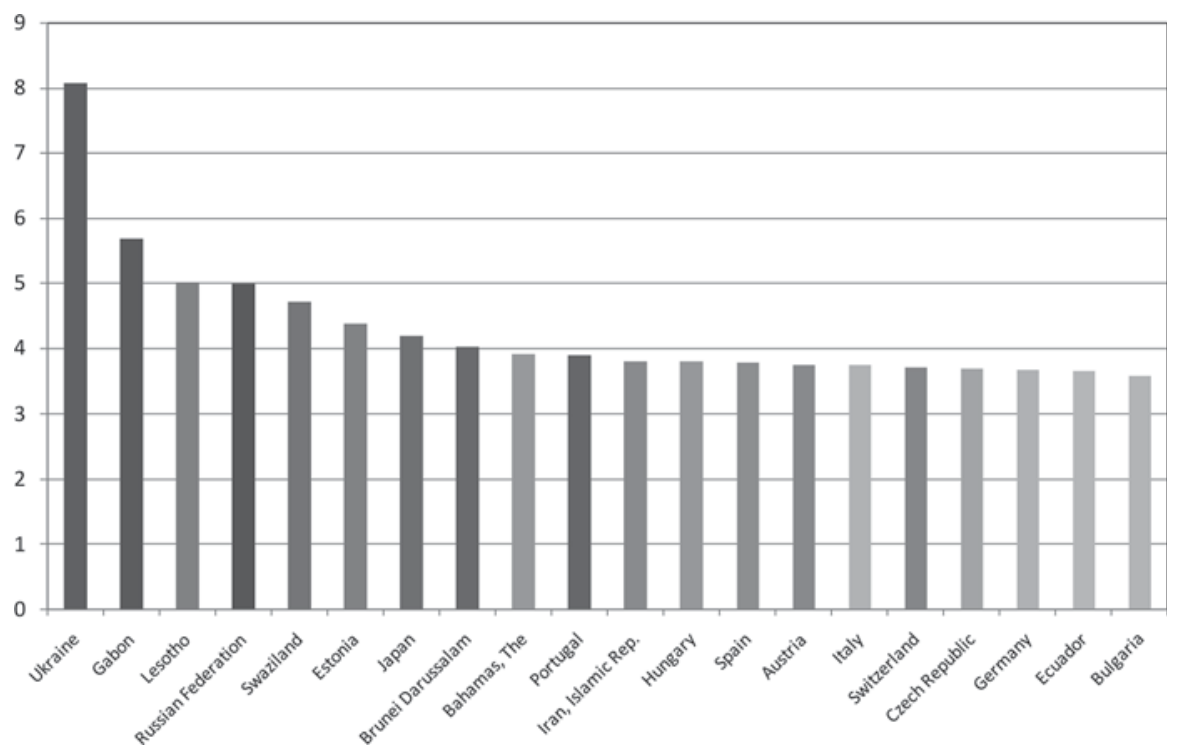

Figure 14: Countries with highest capital coefficients in 2010 (based on USD of 2000) 
Interestingly enough, the mean capital coefficient of our sample countries remained quite stable in between 1991 and 2010. It fell only slightly from 3.17 in 1991 to 3.00 in 2010. Moreover, the capital coefficients show a strong tendency to converge, as the standard deviation decreased from 1.75 to 0.93 throughout the last two decades.

\section{Summary and Conclusions}

The lack of internationally comparable capital stock data has been a major obstacle to empirical multi-country research on the role of physical capital in the process of economic growth. While recently some databases have been extended by measures of the capital stock, these measures are derived from various different sources and thus inter-country comparability is not ensured. In order to avoid this problem, the scientific literature has constructed capital stock data using various different implementations of the Perpetual Inventory Method in the past, thereby relying on one and the same data source for all sample countries. However, the construction of capital stock estimates is quite time-consuming. Moreover, different implementations of the Perpetual Inventory Method are in use, which likely results in differing capital stock estimations, even when they are based on the same raw data. Often it remains unclear which influence the chosen implementation of the Perpetual Inventory Method has on the results of empirical studies using the resulting capital stock estimates.

In order to show the influence of the various described implementations of the Perpetual Inventory Method on the estimation results we constructed capital stock estimates for all four methods described in this article. In order to make the four methods as comparable as possible we applied the depreciation scheme employed under the Unified Approach to all alternative Implementations of the Perpetual Inventory Method. ${ }^{19}$

In fact, especially in the first years of the resulting time series of capital stock estimates, the four different methods (Steady State Approach, Disequilibrium Approach, Synthetic Approach and the proposed Unified Approach) lead to quite some variety in the estimation results. As an example, the Steady State Approach leads to a capital stock estimate for the United States of $6953 \mathrm{bn}$. USD for the first sample year 1970. Under the three other approaches, the referring estimates are considerably higher: 7557 bn. USD under the Disequilibrium Approach, 7301 bn. USD under the Synthetic Time Series Approach and 7737 bn. USD under the Unified Approach (USD of year 2000). ${ }^{20}$ In order to get some more systematic impression on the variety of the results, derived from the four approaches, we calculated the relative dispersion (as measured by the standard deviation of the forecasts divided by their mean) of the

19 For the Steady State Approach, the Disequilibrium Approach and the Synthetic Time Series Approach we followed the procedures described in section three.

20 Note that none of the different approaches leads to systematically larger or lower estimates for the sample countries. 
Table 2: Dispersion of capital stock estimations from four different approaches

\begin{tabular}{|c|c|c|c|c|c|c|c|c|c|}
\hline & 1970 & 1975 & 1980 & 1985 & 1990 & 1995 & 2000 & 2005 & 2010 \\
\hline & $\begin{array}{l}\text { Std. } \\
\text { Dev. } \\
\text { /Mean }\end{array}$ & $\begin{array}{l}\text { Std. } \\
\text { Dev. } \\
\text { /Mean }\end{array}$ & $\begin{array}{l}\text { Std. } \\
\text { Dev. } \\
\text { /Mean }\end{array}$ & $\begin{array}{l}\text { Std. } \\
\text { Dev. } \\
\text { /Mean }\end{array}$ & $\begin{array}{l}\text { Std. } \\
\text { Dev. } \\
\text { /Mean }\end{array}$ & $\begin{array}{c}\text { Std. } \\
\text { Dev. } \\
\text { /Mean }\end{array}$ & $\begin{array}{l}\text { Std. } \\
\text { Dev. } \\
\text { /Mean }\end{array}$ & $\begin{array}{c}\text { Std. } \\
\text { Dev. } \\
\text { /Mean }\end{array}$ & $\begin{array}{c}\text { Std. } \\
\text { Dev./ } \\
\text { Mean }\end{array}$ \\
\hline Argentina & 0,25 & 0,18 & 0,12 & 0,10 & 0,08 & 0,06 & 0,04 & 0,04 & 0,02 \\
\hline Canada & 0,06 & 0,04 & 0,03 & 0,02 & 0,01 & 0,01 & 0,01 & 0,01 & 0,00 \\
\hline Chile & 0,11 & 0,08 & 0,06 & 0,05 & 0,03 & 0,02 & 0,01 & 0,01 & 0,00 \\
\hline Costa Rica & 0,10 & 0,06 & 0,03 & 0,02 & 0,02 & 0,01 & 0,01 & 0,00 & 0,00 \\
\hline $\begin{array}{l}\text { Dominican } \\
\text { Rep. }\end{array}$ & 0,13 & 0,06 & 0,03 & 0,02 & 0,01 & 0,01 & 0,01 & 0,00 & 0,00 \\
\hline El Salvador & 0,11 & 0,08 & 0,04 & 0,04 & 0,03 & 0,02 & 0,01 & 0,01 & 0,01 \\
\hline Finland & 0,12 & 0,08 & 0,06 & 0,04 & 0,03 & 0,02 & 0,02 & 0,01 & 0,01 \\
\hline Greece & 0,19 & 0,12 & 0,08 & 0,06 & 0,04 & 0,03 & 0,02 & 0,02 & 0,01 \\
\hline Guatemala & 0,12 & 0,08 & 0,04 & 0,03 & 0,02 & 0,02 & 0,01 & 0,01 & 0,01 \\
\hline Honduras & 0,09 & 0,06 & 0,04 & 0,02 & 0,02 & 0,01 & 0,01 & 0,01 & 0,00 \\
\hline Hungary & 0,16 & 0,09 & 0,06 & 0,04 & 0,03 & 0,02 & 0,02 & 0,01 & 0,01 \\
\hline Iceland & 0,11 & 0,07 & 0,05 & 0,03 & 0,02 & 0,02 & 0,01 & 0,01 & 0,01 \\
\hline India & 0,03 & 0,02 & 0,01 & 0,01 & 0,00 & 0,00 & 0,00 & 0,00 & 0,00 \\
\hline Italy & 0,16 & 0,11 & 0,08 & 0,06 & 0,04 & 0,03 & 0,02 & 0,02 & 0,01 \\
\hline Japan & 0,23 & 0,12 & 0,07 & 0,05 & 0,03 & 0,02 & 0,01 & 0,01 & 0,01 \\
\hline Korea, Rep. & 0,12 & 0,05 & 0,02 & 0,01 & 0,01 & 0,00 & 0,00 & 0,00 & 0,00 \\
\hline Luxembourg & 0,04 & 0,03 & 0,02 & 0,01 & 0,01 & 0,01 & 0,00 & 0,00 & 0,00 \\
\hline Malaysia & 0,07 & 0,04 & 0,02 & 0,01 & 0,01 & 0,00 & 0,00 & 0,00 & 0,00 \\
\hline Mexico & 0,13 & 0,08 & 0,05 & 0,03 & 0,02 & 0,01 & 0,01 & 0,01 & 0,01 \\
\hline Nicaragua & 0,27 & 0,17 & 0,11 & 0,08 & 0,06 & 0,05 & 0,04 & 0,03 & 0,02 \\
\hline Norway & 0,11 & 0,08 & 0,05 & 0,04 & 0,03 & 0,02 & 0,02 & 0,01 & 0,01 \\
\hline Pakistan & 0,10 & 0,07 & 0,05 & 0,03 & 0,02 & 0,01 & 0,01 & 0,01 & 0,01 \\
\hline Peru & 0,14 & 0,10 & 0,07 & 0,05 & 0,03 & 0,03 & 0,02 & 0,01 & 0,01 \\
\hline Philippines & 0,09 & 0,06 & 0,03 & 0,02 & 0,02 & 0,01 & 0,01 & 0,01 & 0,00 \\
\hline Sweden & 0,13 & 0,09 & 0,06 & 0,05 & 0,04 & 0,03 & 0,02 & 0,02 & 0,01 \\
\hline Switzerland & 0,15 & 0,10 & 0,08 & 0,06 & 0,04 & 0,03 & 0,02 & 0,02 & 0,01 \\
\hline Thailand & 0,13 & 0,07 & 0,04 & 0,02 & 0,01 & 0,01 & 0,00 & 0,00 & 0,00 \\
\hline Tunisia & 0,08 & 0,06 & 0,03 & 0,02 & 0,01 & 0,01 & 0,01 & 0,01 & 0,00 \\
\hline $\begin{array}{l}\text { United } \\
\text { States }\end{array}$ & 0,04 & 0,03 & 0,02 & 0,01 & 0,01 & 0,01 & 0,00 & 0,00 & 0,00 \\
\hline Uruguay & 0,14 & 0,11 & 0,07 & 0,05 & 0,04 & 0,03 & 0,02 & 0,02 & 0,01 \\
\hline $\begin{array}{l}\text { Venezuela } \\
\text { RB }\end{array}$ & 0,12 & 0,08 & 0,05 & 0,03 & 0,03 & 0,02 & 0,02 & 0,01 & 0,01 \\
\hline
\end{tabular}


capital stock forecasts on a country basis and in steps of 5 years. The results are shown in table 2. In order to be able to track the dispersion over time we only included those countries into the comparison for which it was possible to generate capital stock forecasts for the whole sample period. The table illustrates that the four methods lead to quite some variety in forecasts in the early years of the sample period. However, the results derived under the various methods converge quite quickly in the course of time, at least if the same capital depreciation scheme is used under all methods (which holds not true in the existing scientific literature, where most often different constant depreciation schemes have been employed).

The sample only consists of countries for which capital stock estimates based on all four implementation methods of the Perpetual Inventory Method were available.

As we argued earlier, a comparison of the capital estimates resulting under the various methods reveals no information on which of the implementation methods of the Perpetual Inventory Method is favorable. Our proposal of the Unified Approach thus is not based on such a comparison but rather on theoretical reasoning. By providing a large dataset of aggregate capital stock estimates for 103 countries around the globe we aim at stimulating empirical cross-country research on the role of capital in the process of economic growth. The resulting dataset is large enough to allow pure cross section analyses as well as panel studies. At least for the subsample of countries, for which investment data is available since 1970, the data can even be used to conduct time-series analyses. However, since for many countries (internationally incomparable) official aggregate capital stock data is available, one might prefer the official data for the latter purpose.

\section{References}

BARro, R. J. (1991): Economic Growth in a Cross Section of Countries. Quarterly Journal of Economics 106 (2), 407-443.

Benhabib, J. and M. M. Spiegel (1994): The role of human capital in economic development. Evidence from aggregate cross-country data. Journal of Monetary Economics $34,143-173$.

Bureau of Economic Analysis (2003): Fixed Assets and Consumer Durable Goods in the United States, 1925-99. Washington, DC: U.S. Government Printing Office, September.

Derbyshire, J., Gardiner, B. and S. Waights (2013): Estimating the capital stock for the NUTS2 regions of the EU27. Applied Economics 45 (9), 1133-1149.

de la Fuente, A. and R. Domenech (2000): Human Capital in Growth Regressions: How Much Difference Does Data Quality Make? Economics Department Working Paper, 262, OECD, Paris.

Griliches, Z. (1980): R\&D and the Productivity Slowdown. NBER Working Paper Series, 434, Cambridge/Mass.

Harberger, A. C. (1978): Perspectives on Capital and Technology in Less Developed Countries. In: M. J. Artis and A. R. Nobay (Eds.): Contemporary Economic Analysis, London, 42-72. 
Hodrick, R. J. and E. C. Prescott (1997): Post-war US business cycles: An empirical investigation. Journal of Money, Credit and Banking 29, 1-16.

InklaAr, R. and M. P. Timmer (2013): Capital, labor and TFP in PWT8.0, Working Paper, July.

Jacob, V., Sharma, S. C. and R. Grabowsky (1997): Capital Stock Estimates for Major Esctors and Disaggregated Manufacturing in Selected OECD Countries. Applied Economics 29, 563-579.

Kamps, C. (2006): New Estimates of Government Net Capital Stocks for 22 OECD Countries 1960-2001. IMF Staff Paper 53 (1), 120-150.

Mise, E., Kim, T.-H. and P. Newbold (2005): On suboptimality of the Hodrick-Prescott filter at time series endpoints. Journal of Macroeconomics 27, 53-67.

Nehru, V. and A. Dhareshwar (1993): A new database on physical capital stock: Sources, methodology and results. Revista de Analisis Economico 8(1), 37-59.

Schmalwasser, O. and M. Schidlowski (2006): Kapitalstockrechnung in Deutschland. Wirtschaft und Statistik (11/2006), 1107-1123.

Schreyer, P., Arnaud, B., Dupont, J. and S.-H. Koh (2011): Measuring Multi-Factor Productivity by Industry: Methodology and First Results from the OECD Productivity Database, OECD.

Statistics Canada (2001): Investment Flows and Capital Stocks. Methodology. Downlad: http://www23.statcan.gc.ca/imdb-bmdi/document/2820_D1_T9_V1_B.pdf (May 2014). 


\section{Appendix}

Table A-1: Start and end of capital stock time series by country

\begin{tabular}{|c|c|c|}
\hline Country & Start & End \\
\hline Algeria & 1968 & 2010 \\
\hline Argentina & 1960 & 2010 \\
\hline Armenia & 1989 & 2010 \\
\hline Australia & 1964 & 2010 \\
\hline Austria & 1969 & 2010 \\
\hline Azerbaijan & 1989 & 2010 \\
\hline Bahamas, The & 1988 & 2010 \\
\hline Bangladesh & 1979 & 2010 \\
\hline Belarus & 1989 & 2010 \\
\hline Belgium & 1969 & 2010 \\
\hline Bolivia & 1969 & 2010 \\
\hline Botswana & 1973 & 2010 \\
\hline Brazil & 1969 & 2010 \\
\hline Brunei Darussalam & 1988 & 2010 \\
\hline Bulgaria & 1979 & 2010 \\
\hline Cameroon & 1974 & 2010 \\
\hline Canada & 1960 & 2010 \\
\hline Cape Verde & 1985 & 2010 \\
\hline Chile & 1960 & 2010 \\
\hline China & 1964 & 2010 \\
\hline Costa Rica & 1960 & 2010 \\
\hline Cuba & 1969 & 2010 \\
\hline Cyprus & 1974 & 2010 \\
\hline Czech Republic & 1989 & 2010 \\
\hline Denmark & 1965 & 2010 \\
\hline Dominican Republic & 1960 & 2010 \\
\hline Ecuador & 1964 & 2010 \\
\hline Egypt, Arab Rep. & 1964 & 2010 \\
\hline El Salvador & 1960 & 2010 \\
\hline Estonia & 1987 & 2010 \\
\hline Ethiopia & 1980 & 2010 \\
\hline Finland & 1960 & 2010 \\
\hline France & 1969 & 2010 \\
\hline
\end{tabular}


Table A-1: continued

\begin{tabular}{|c|c|c|}
\hline Country & Start & End \\
\hline Gabon & 1979 & 2010 \\
\hline Germany & 1969 & 2010 \\
\hline Greece & 1960 & 2010 \\
\hline Guatemala & 1960 & 2010 \\
\hline Guinea & 1985 & 2010 \\
\hline Honduras & 1960 & 2010 \\
\hline Hong Kong SAR, China & 1964 & 2010 \\
\hline Hungary & 1960 & 2010 \\
\hline Iceland & 1960 & 2010 \\
\hline India & 1960 & 2010 \\
\hline Indonesia & 1978 & 2010 \\
\hline Iran, Islamic Rep. & 1964 & 2010 \\
\hline Ireland & 1969 & 2010 \\
\hline Italy & 1960 & 2010 \\
\hline Japan & 1960 & 2010 \\
\hline Jordan & 1975 & 2010 \\
\hline Kazakhstan & 1989 & 2010 \\
\hline Kenya & 1978 & 2010 \\
\hline Korea, Rep. & 1960 & 2010 \\
\hline Kyrgyz Republic & 1989 & 2010 \\
\hline Latvia & 1989 & 2010 \\
\hline Lesotho & 1969 & 2010 \\
\hline Luxembourg & 1960 & 2010 \\
\hline Macao SAR, China & 1981 & 2010 \\
\hline Macedonia, FYR & 1989 & 2010 \\
\hline Madagascar & 1983 & 2010 \\
\hline Malaysia & 1960 & 2010 \\
\hline Mali & 1978 & 2010 \\
\hline Malta & 1969 & 2010 \\
\hline Mauritius & 1975 & 2010 \\
\hline Mexico & 1960 & 2010 \\
\hline Moldova & 1990 & 2010 \\
\hline Morocco & 1965 & 2010 \\
\hline Mozambique & 1979 & 2010 \\
\hline Namibia & 1979 & 2010 \\
\hline Netherlands & 1969 & 2010 \\
\hline
\end{tabular}


Table A-1: continued

\begin{tabular}{|c|c|c|}
\hline Country & Start & End \\
\hline New Zealand & 1969 & 2010 \\
\hline Nicaragua & 1960 & 2010 \\
\hline Norway & 1960 & 2010 \\
\hline Pakistan & 1960 & 2010 \\
\hline Panama & 1979 & 2010 \\
\hline Paraguay & 1964 & 2010 \\
\hline Peru & 1960 & 2010 \\
\hline Philippines & 1960 & 2010 \\
\hline Poland & 1989 & 2010 \\
\hline Portugal & 1969 & 2010 \\
\hline Romania & 1989 & 2010 \\
\hline Russian Federation & 1989 & 2010 \\
\hline Senegal & 1964 & 2010 \\
\hline Seychelles & 1983 & 2010 \\
\hline Singapore & 1974 & 2010 \\
\hline Slovenia & 1989 & 2010 \\
\hline Spain & 1969 & 2010 \\
\hline Sudan & 1975 & 2010 \\
\hline Swaziland & 1979 & 2010 \\
\hline Sweden & 1960 & 2010 \\
\hline Switzerland & 1960 & 2010 \\
\hline Syrian Arab Republic & 1974 & 2010 \\
\hline Tajikistan & 1984 & 2010 \\
\hline Tanzania & 1989 & 2010 \\
\hline Thailand & 1960 & 2010 \\
\hline Tunisia & 1960 & 2010 \\
\hline Turkey & 1986 & 2010 \\
\hline Uganda & 1981 & 2010 \\
\hline Ukraine & 1989 & 2010 \\
\hline United Kingdom & 1969 & 2010 \\
\hline United States & 1960 & 2010 \\
\hline Uruguay & 1960 & 2010 \\
\hline Venezuela, RB & 1960 & 2010 \\
\hline Zambia & 1969 & 2010 \\
\hline
\end{tabular}




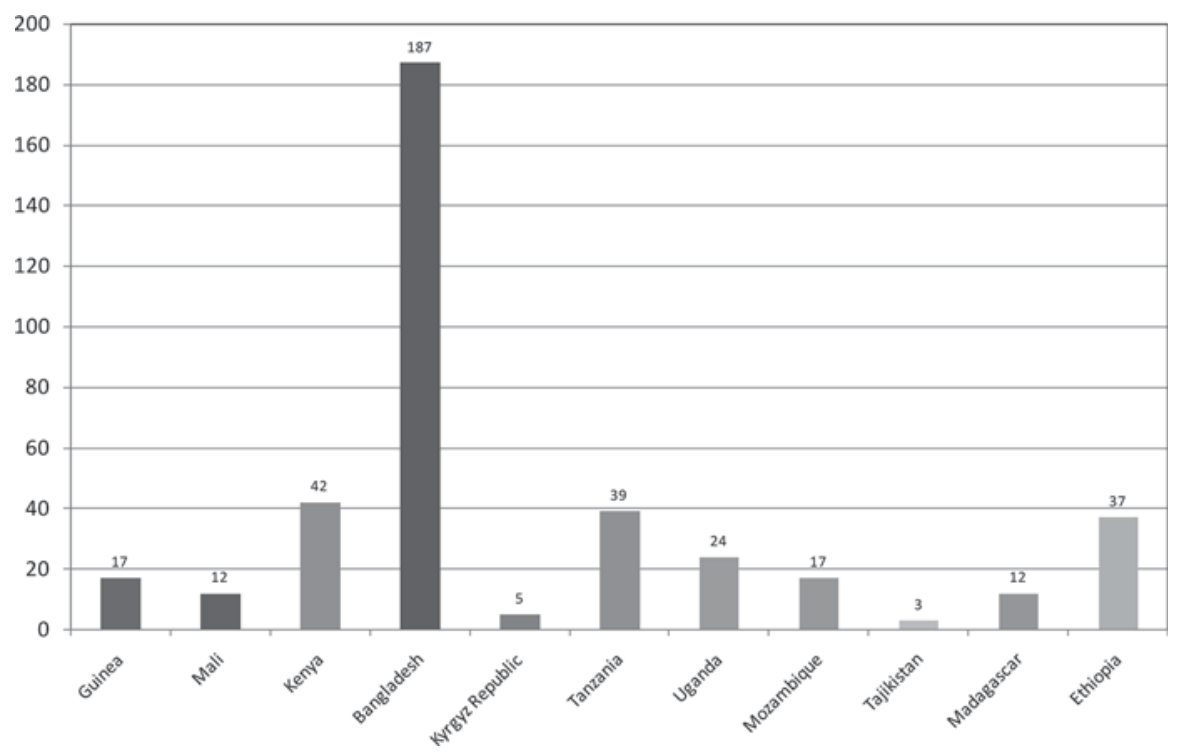

Figure A-1: Aggregate capital stocks in low income countries (in bn. USD of 2000)

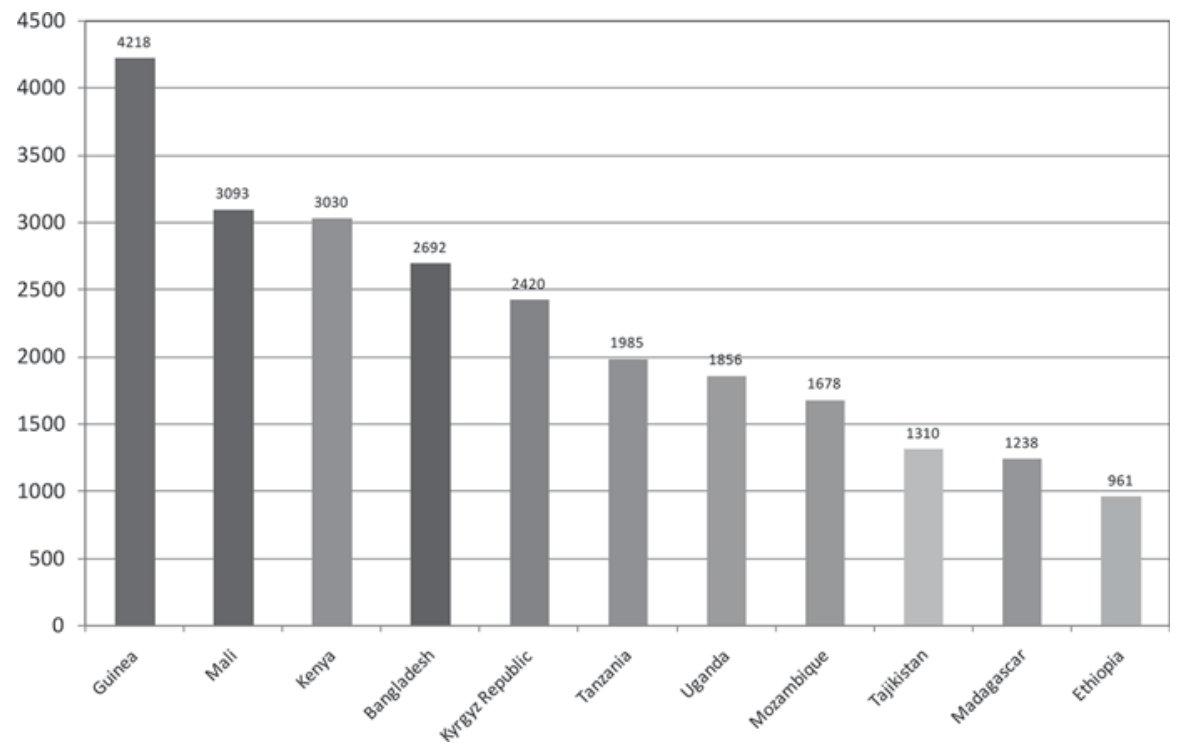

Figure A-2: Capital intensities in low income countries (in USD of 2000) 


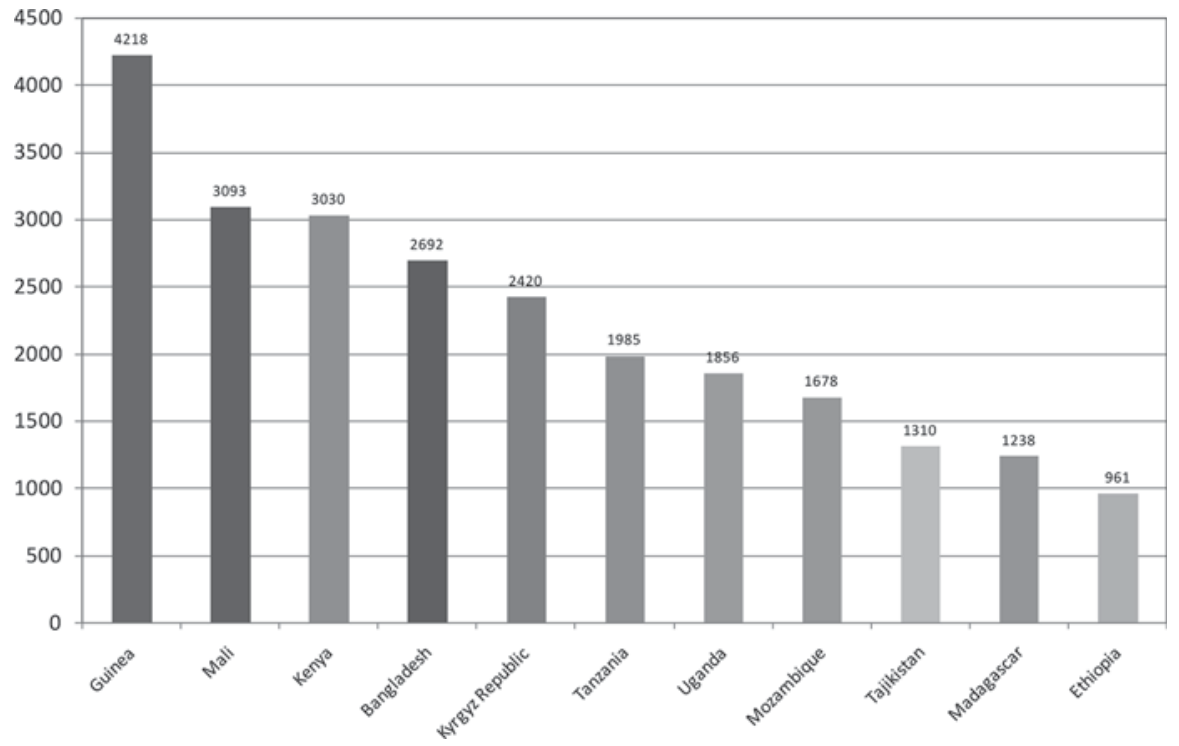

Figure A-3: Capital coefficients in low income countries (based on USD of 2000)

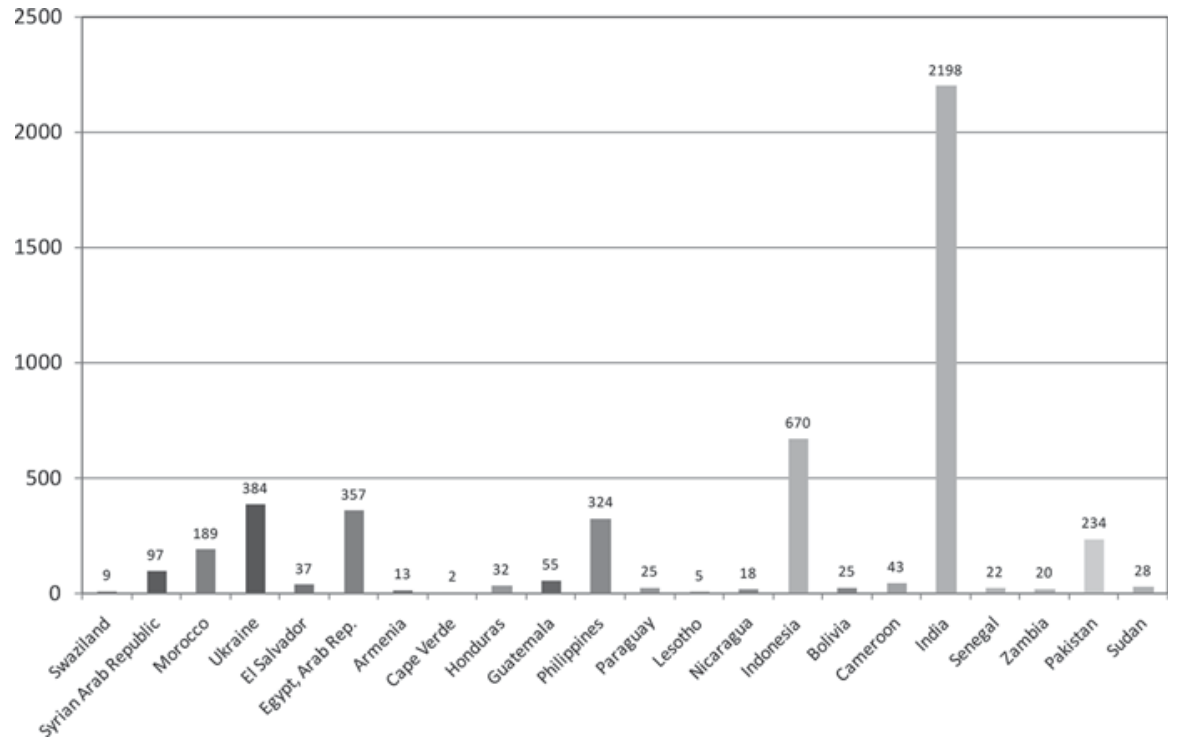

Figure A-4: Aggregate capital stocks in lower middle income countries (in bn. USD of 2000) 


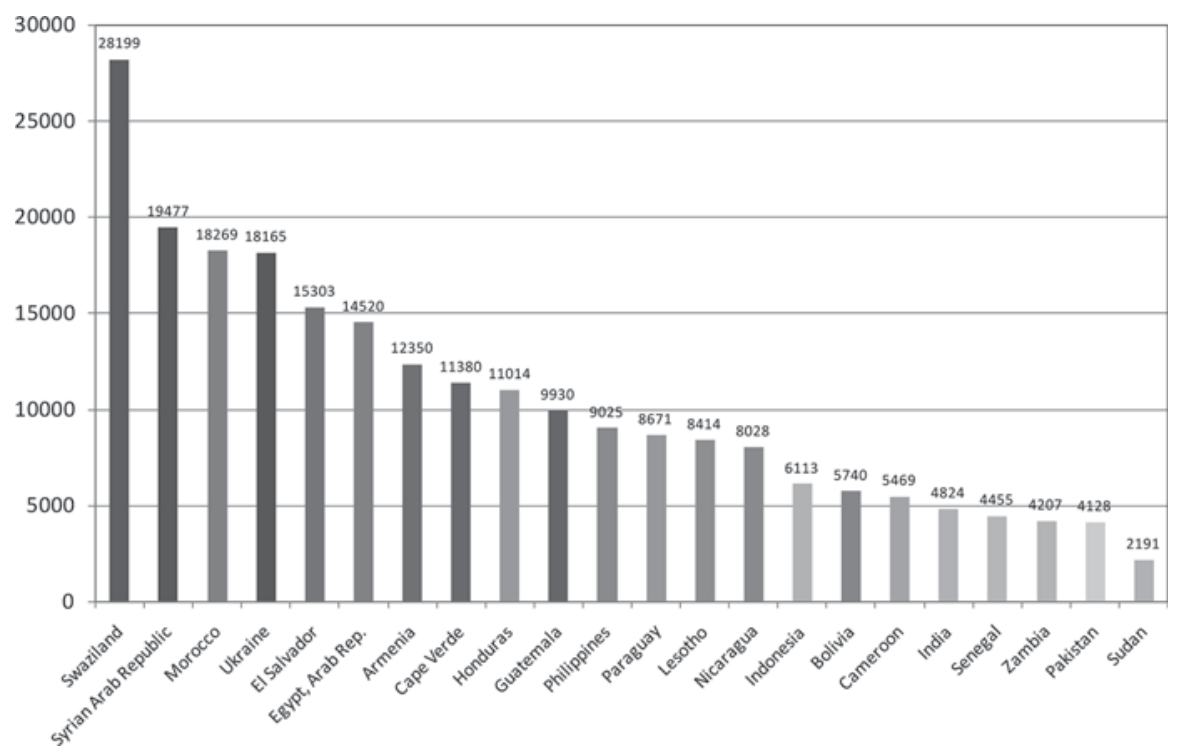

Figure A-5: Capital intensities in lower middle income countries (in USD of 2000)

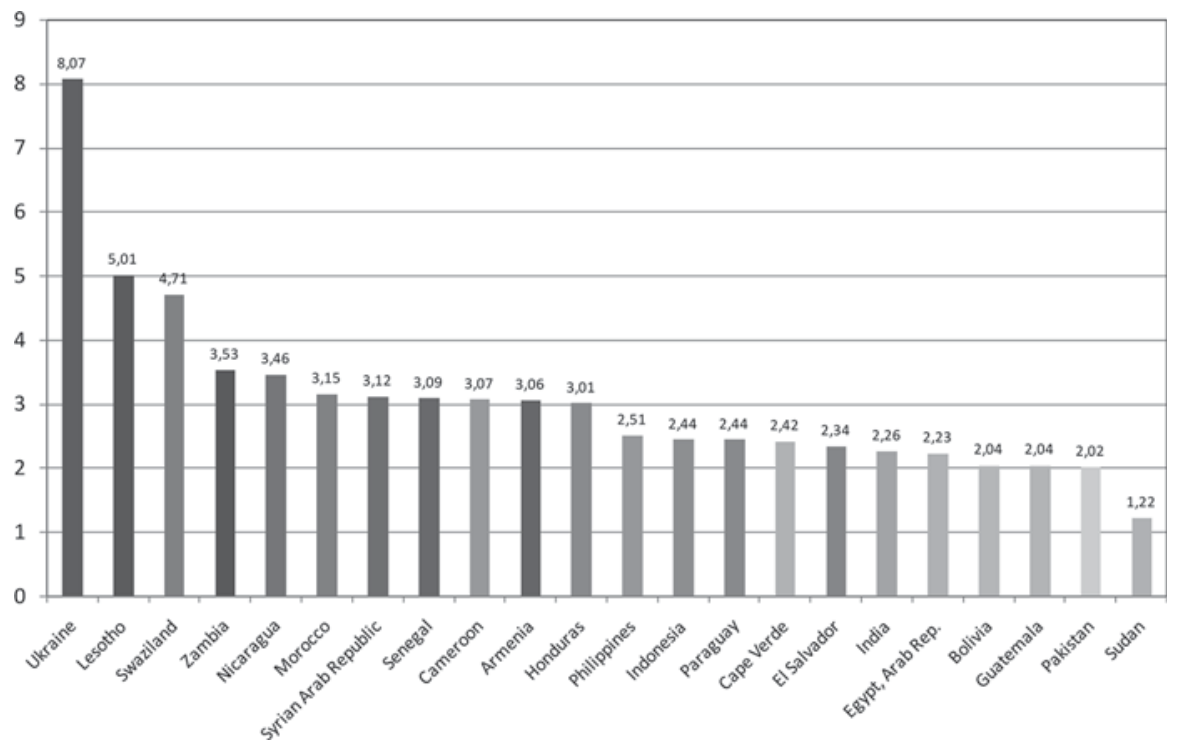

Figure A-6: Capital coefficients in lower middle income countries (based on USD of 2000) 


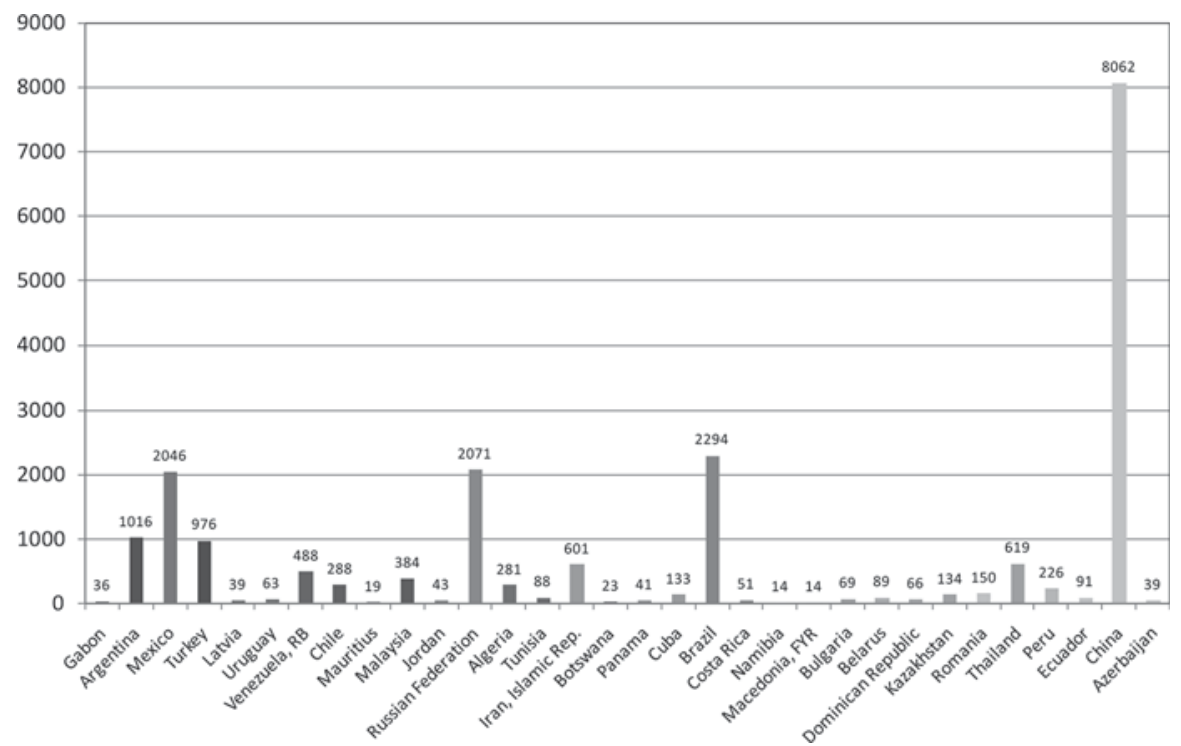

Figure A-7: Aggregate capital stocks in upper middle income countries (in bn. USD of 2000)

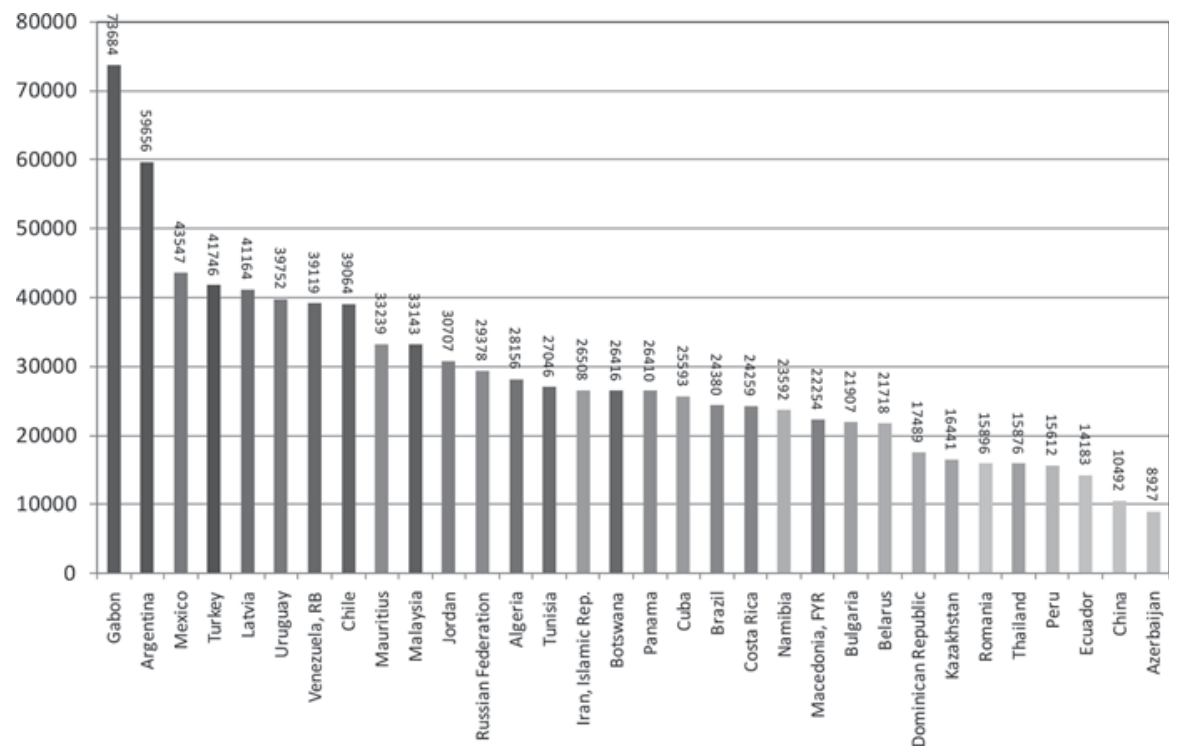

Figure A-8: Capital intensities in upper middle income countries (in USD of 2000) 


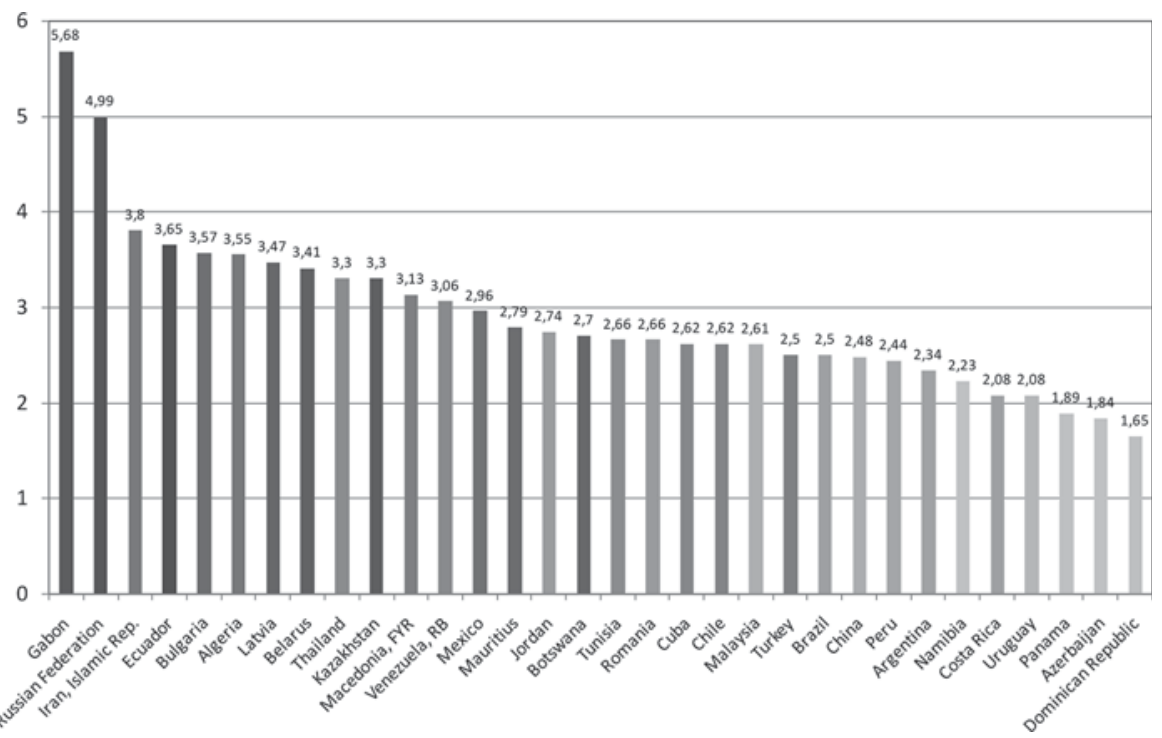

Figure A-9: Capital coefficients in upper middle income countries (based on USD of 2000)

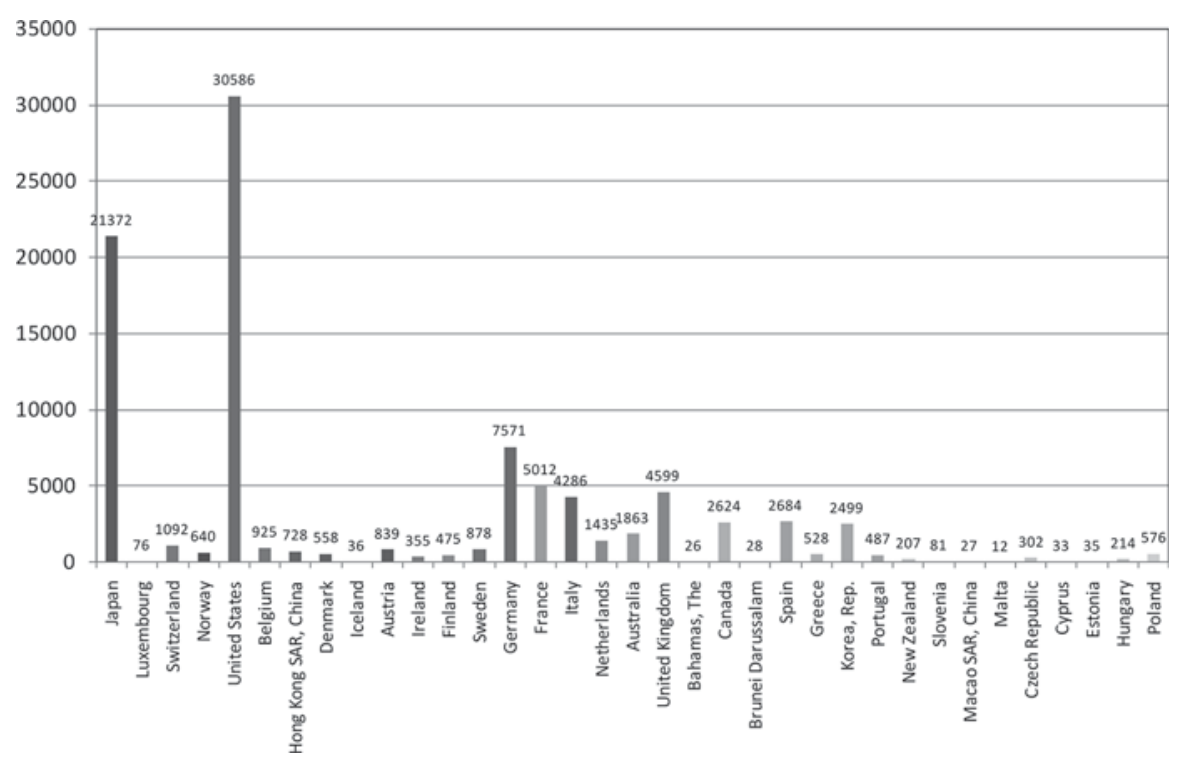

Figure A-10: Aggregate capital stocks in high income countries (in bn. USD of 2000) 


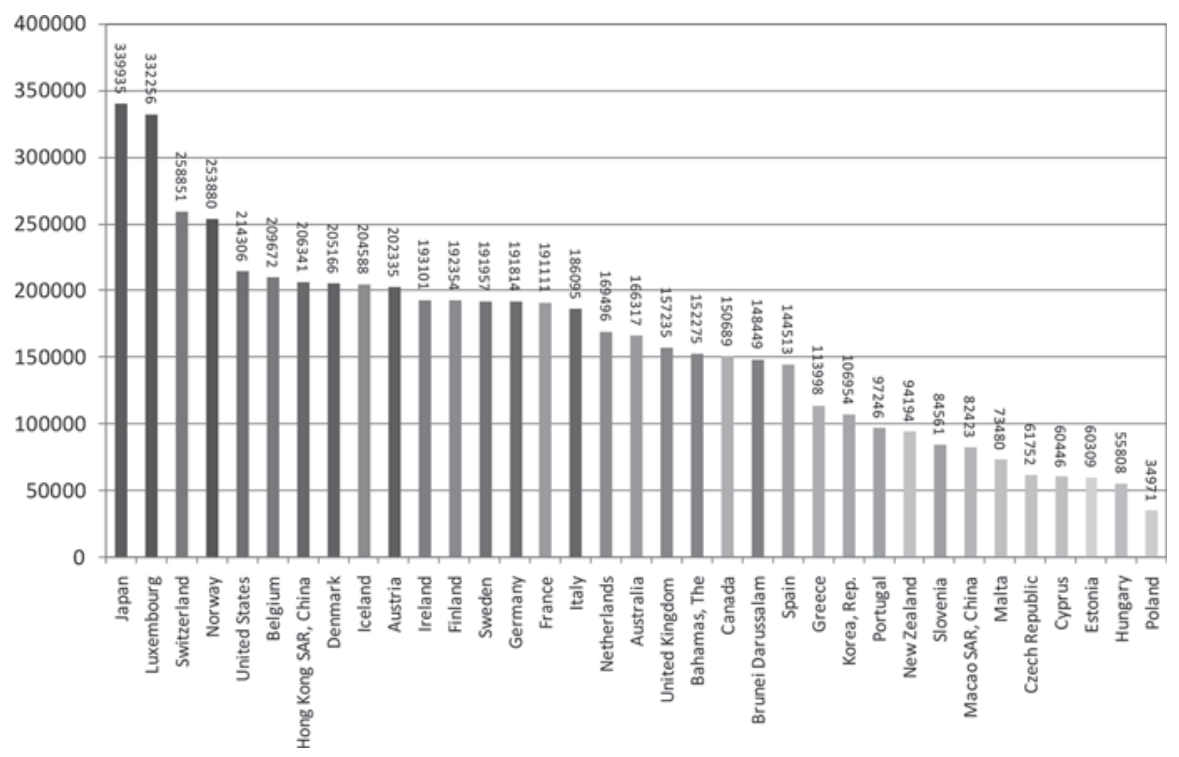

Figure A-11: Capital intensities in high income countries (in USD of 2000)

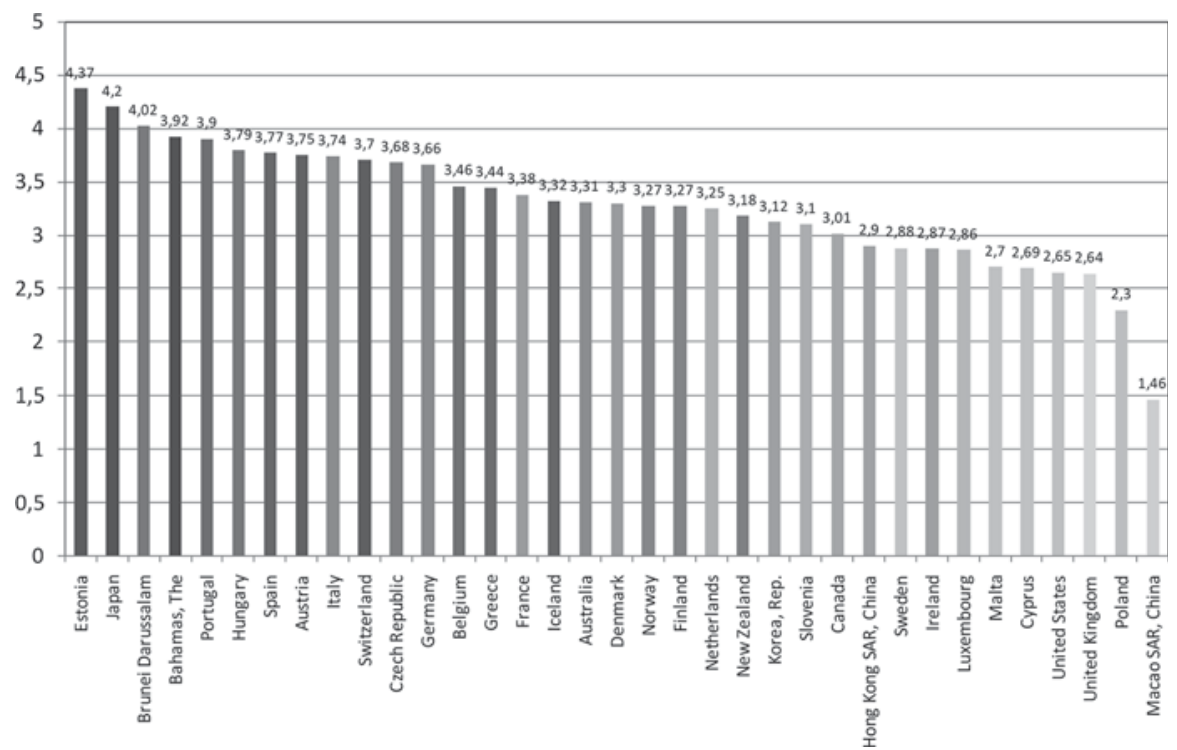

Figure A-12: Capital coefficients in high income countries (based on USD of 2000) 